\title{
A candidate anti-HIV reservoir compound, auranofin, exerts a selective 'anti-memory' effect by exploiting the baseline oxidative status of lymphocytes
}

\author{
B Chirullo ${ }^{1,9}$, R Sgarbanti ${ }^{2,9}$, D Limongi ${ }^{2}$, IL Shytaj ${ }^{1}$, D Alvarez ${ }^{3}$, B Das ${ }^{3}$, A Boe ${ }^{1}$, S DaFonseca ${ }^{4}$, N Chomont ${ }^{4}$, L Liotta ${ }^{5}$, E III Petricoin ${ }^{5}$,

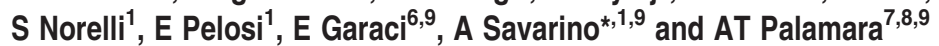

Central memory $\left(\mathrm{T}_{\mathrm{CM}}\right)$ and transitional memory $\left(\mathrm{T}_{\mathrm{TM}}\right) \mathrm{CD} 4^{+} \mathrm{T}$ cells are known to be the major cellular reservoirs for HIV, as these cells can harbor a transcriptionally silent form of viral DNA that is not targeted by either the immune system or current antiretroviral drug regimens. In the present study, we explored the molecular bases of the anti-HIV reservoir effects of auranofin (AF), a pro-oxidant gold-based drug and a candidate compound for a cure of AIDS. We here show that $\mathrm{T}_{\mathrm{CM}}$ and $\mathrm{T}_{\mathrm{TM}}$ lymphocytes have lower baseline antioxidant defenses as compared with their naive counterpart. These differences are mirrored by the effects exerted by AF on T-lymphocytes: AF was able to exert a pro-differentiating and pro-apoptotic effect, which was more pronounced in the memory subsets. AF induced an early activation of the p38 mitogen-activated protein kinase (p38 MAPK) followed by mitochondrial depolarization and a final burst in intracellular peroxides. The pro-differentiating effect was characterized by a downregulation of the CD27 marker expression. Interestingly, AF-induced apoptosis was inhibited by pyruvate, a well-known peroxide scavenger, but pyruvate did not inhibit the pro-differentiating effect of AF, indicating that the pro-apoptotic and pro-differentiating effects involve different pathways. In conclusion, our results demonstrate that AF selectively targets the $\mathrm{T}_{\mathrm{CM}} / \mathrm{T}_{\mathrm{TM}}$ lymphocyte subsets, which encompass the HIV reservoir, by affecting redox-sensitive cell death pathways.

Cell Death and Disease (2013) 4, e944; doi:10.1038/cddis.2013.473; published online 5 December 2013

Subject Category: Experimental Medicine

The gold compound auranofin (AF) is a candidate drug for curing HIV infection, showing the potential to hit crucial therapeutic targets that are not accessible to the antiretroviral drugs (ARVs) currently in use. ${ }^{1-5}$ Although ARVs are able to clear viremia and improve the immunological condition of HIVinfected individuals for prolonged time, ${ }^{6}$ the virus rebounds to levels comparable to those observed before treatment initiation shortly after treatment is withdrawn. ${ }^{6} \mathrm{AF}$ is the first drug shown to induce a partially selective killing of central and transitional memory $\mathrm{T}$ cells (henceforth $\mathrm{T}_{\mathrm{CM}}$ and $\mathrm{T}_{\mathrm{TM}}$, respectively ${ }^{7}$ ), which are pivotal carriers of HIV during conventional therapies. ${ }^{8} \mathrm{~T}_{\mathrm{CM}}$ and $\mathrm{T}_{\mathrm{TM}}$ constitute one main viral reservoir that is long-lived and harbors dormant proviral DNA copies integrated in the genome that cannot be targeted by either the immune system or drug-based therapies. However, different stimuli can reactivate proviral DNA to produce new infectious viral particles. ${ }^{9,10}$
Also in vivo AF showed the potential to target the viral reservoir, given its ability to induce cell death in the memory T-cell compartment (recently reviewed in Badley et al. ${ }^{1}$ ). In this regard, we recently showed in the macaque AIDS model (i.e., rhesus macaques chronically infected with the HIV simian homolog, SIVmac251) that treatment with a drug combination consisting of ARVs and AF is able to induce a long-term reduction in the post-therapy viral set point following therapy suspension. ${ }^{7,11}$ Importantly, the effects of AF on the memory cell subset were not associated with any detectable immune impairment in vivo. Moreover, we recently proved that the effects of AF can be enhanced in the context of a combined anti-reservoir therapy, inducing a drug-free remission of the disease in chronically SIVmac251-infected macaques. ${ }^{12}$

Despite the extensive study of gold salts conducted throughout the centuries, ${ }^{13-15}$ a comprehensive picture of the effects and mechanism of action of AF on the immune

\footnotetext{
${ }^{1}$ Istituto Superiore di Sanità, Viale Regina Elena, 299, Rome, Italy; ${ }^{2}$ Scientific Institute for Research, Hospitalization and Health Care, Università Telematica San Raffaele, Rome, Italy; ${ }^{3}$ Department of Molecular Biology and Microbiology, Case Western Reserve University School of Medicine, Cleveland, OH, USA; ${ }^{4} \mathrm{Vaccine}$ and Gene Therapy Institute Florida, Port St Lucie, FL, USA; ${ }^{5}$ Center for Applied Proteomics and Molecular Medicine, George Mason University, Manassas, VA, USA; ${ }^{6}$ Department of Experimental Medicine and Surgery, University of Rome Tor Vergata, Rome, Italy; ${ }^{7}$ Dept of Public Health and Infectious Diseases, Institute Pasteur Cenci Bolognetti Foundation, Sapienza University of Rome, Rome, Italy and ${ }^{8}$ San Raffaele Pisana Scientific Institute for Research, Hospitalization and Health Care, Rome, Italy

*Corresponding author: A Savarino, Istituto Superiore di Sanità, Viale Regina Elena, 299, Rome 00161, Italy. Tel: +39 0649902305; Fax: +39 0649903561; E-mail: andrea.savarino@iss.it

${ }^{9}$ These authors contributed equally to this work.

Keywords: auranofin; HIV cure; memory compartment; apoptosis; differentiation effect; oxidative stress

Abbreviations: AF, auranofin; AIDS, acquired immunodeficiency syndrome; $\mathrm{As}_{2} \mathrm{O}_{3}$, arsenic trioxide; ART, antiretroviral therapy; ARV, antiretroviral drug; DHR, dihydrorhodamine; FACS, fluorescence-activated cell sorting (flow cytometry); GSH, glutathione; HIV, human immunodeficiency virus; MAPK, mitogen-activated protein kinases; MMP, mitochondrial membrane potential; PBMC, peripheral blood mononuclear cell; RNA, ribonucleic acid; ROS, reactive oxygen species; RPMA, reverse phase protein microarray; SIV, simian immunodeficiency virus; $T_{N}$, naive $T$ cells; $T_{C M}$, central memory $T$ cells; $T_{E M}$, effector memory $T$ cells; TrxRs, thioredoxin reductases; $\mathrm{T}_{\mathrm{TM}}$, transitional memory $\mathrm{T}$ cells

Received 10.9.13; revised 26.10.13; accepted 31.10.13; Edited by G Melino
} 
system is still lacking, particularly in the $\mathrm{CD}^{+}{ }^{+} \mathrm{T}$-cell compartment. It is known that AF impairs the proliferative capacity of T-lymphocytes in vitro ${ }^{16,17}$ and decreases production of pro-inflammatory cytokines in macrophages and $\mathrm{T}$ cells. ${ }^{18,19}$ Moreover, AF has been shown to induce intracellular oxidative stress by compromising the antioxidant defense due to the inhibition of thioredoxin reductase (TrxR). ${ }^{20,21}$ However, the molecular pathways associated with these effects have been characterized in detail only in tumor cells, never in primary lymphocytes. ${ }^{22,23}$

In the present study, we show that the main antioxidant defenses of the cell decrease paralleling the lymphocyte differentiation stage. This deficiency of antioxidant defense in differentiated memory $\mathrm{CD}^{+}{ }^{+} \mathrm{T}$ cells is associated with increased susceptibility to a signaling cascade sparked by AF and leading to cell death. These findings suggest the molecular bases upon which the anti-reservoir effects of AF are grounded.

\section{Results}

AF exerts cytocidal and pro-differentiating effects on different lymphocyte memory T-cell compartments in vitro. In a previous study, we analyzed the in vivo and in vitro effects of $\mathrm{AF}^{7}$ on $\mathrm{CD}^{+} \mathrm{T}$-cell subpopulations in peripheral blood of rhesus macaques infected with SIVmac251 and treated with antiretroviral therapy (ART) plus AF. We showed that AF induced a significant reduction in the frequency of the long-lived $\mathrm{T}_{\mathrm{CM}} / \mathrm{T}_{\mathrm{TM}}$ cells. ${ }^{7} \mathrm{We}$ first aimed at confirming these effects of $\mathrm{AF}$ on sorted $\mathrm{CD}_{4}{ }^{+} \mathrm{T}$-cell subpopulations isolated from a cohort of uninfected human donors. For this purpose, we measured, by flow cytometry, the expression of CD27, that is, a marker for long-lived phenotypes, and the frequency of Annexin $\mathrm{V}^{+}$cells, that is, a predictive marker for apoptosis. The results confirmed that AF induced CD27 downmodulation with a concomitant increase in the frequency of Annexin $\mathrm{V}^{+}$cells (Figure 1a). Annexin $\mathrm{V}$ staining was more pronounced in the memory compartment, including $\mathrm{T}_{\mathrm{CM}}$ and $\mathrm{T}_{\mathrm{TM}}$ lymphocytes, that is, the cell types that encompass the HIV- 1 reservoirs $(P<0.05$, repeated measures ANOVA followed by the Newman-Keuls post-hoc test, five donors). These results confirm and extend those previously obtained in vitro in human CD4 ${ }^{+} \mathrm{T}$ cells and in vivo in SIVmac251-infected macaques. ${ }^{7}$

As during the progression of $\mathrm{HIV}$ infection the $\mathrm{T}_{\mathrm{CM}}$ and $\mathrm{T}_{\mathrm{TM}}$ $\mathrm{CD}^{+}{ }^{+} \mathrm{T}$ cells become activated ${ }^{24}$ and this activation correlates with disease progression, ${ }^{25}$ we analyzed whether AF might also shorten the lifespan of the $\mathrm{T}_{\mathrm{CM}}$ and $\mathrm{T}_{\mathrm{TM}}$ compartments of $\mathrm{CD}^{+} \mathrm{T}$ cells. Experiments conducted in sorted CD8 ${ }^{+} \mathrm{T}$-cell
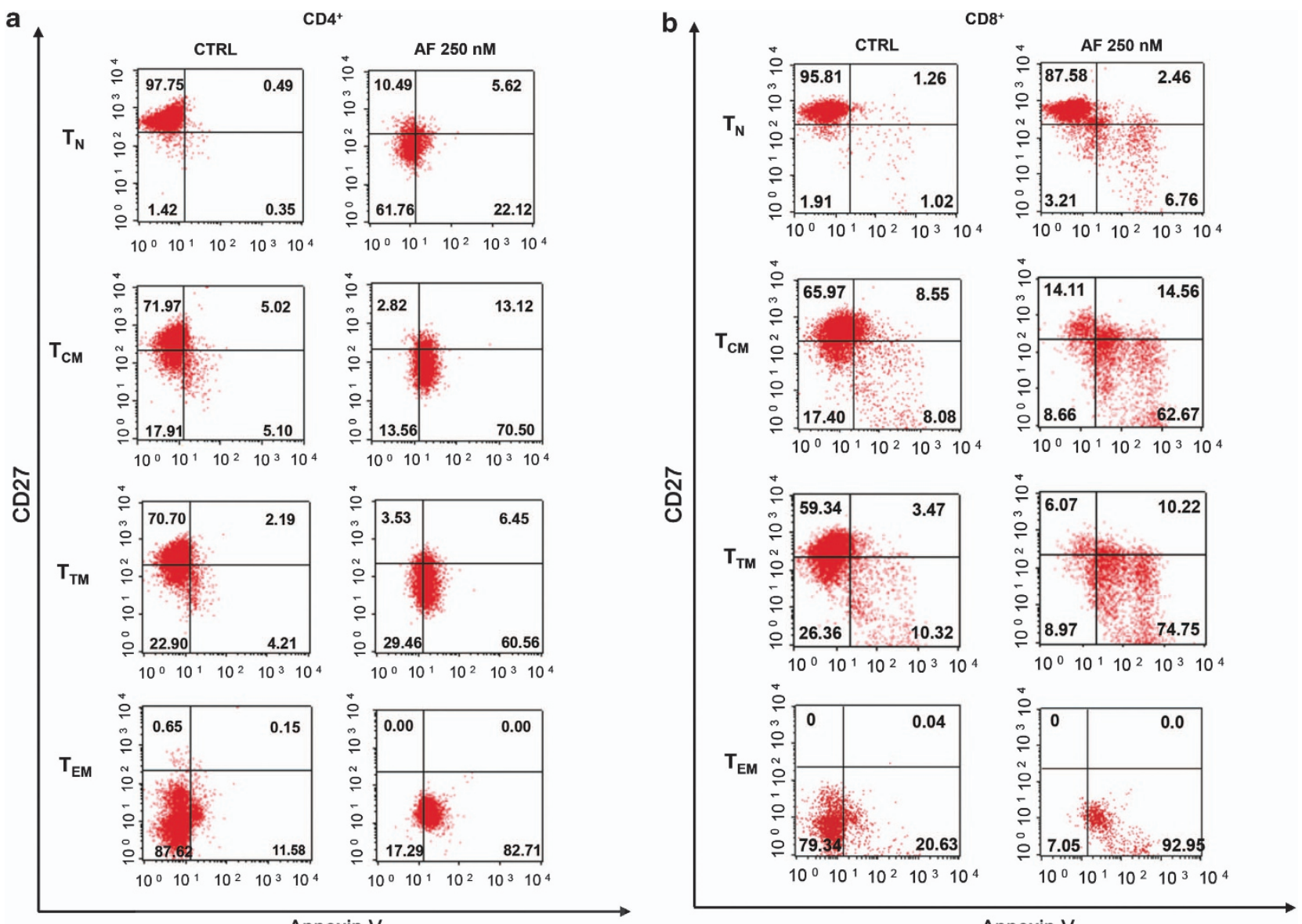

Annexin V

Annexin V

Figure 1 Dot plots showing anti-CD27 and Annexin $V$ staining after $48 \mathrm{~h}$ of treatment with $\mathrm{AF}$ (gate on live cells) in (a) $\mathrm{CD} 4^{+}$and (b) $\mathrm{CD} 8^{+}{ }^{+}$-cell subpopulations. CD4 ${ }^{+}$ and $C D 8^{+} T_{N}, T_{C M}, T_{T M}$ and $T_{E M} T$ cells were separated by sorting and treated with AF at $250 \mathrm{nM}$ or left untreated (gated on live CD4 ${ }^{+} \mathrm{T}$ cells on the basis of the physical parameters). The dot plots show data from one representative experiment out of five (a) and out of three (b) with similar results 
subpopulations showed that, similar to what was observed in $\mathrm{CD}^{+}{ }^{+} \mathrm{T}$ cells, CD8 ${ }^{+} \mathrm{T}_{\mathrm{CM}}, \mathrm{T}_{\mathrm{TM}}$ and effector memory $\mathrm{T}\left(\mathrm{T}_{\mathrm{EM}}\right)$ lymphocytes succumbed more readily than the naive $\left(T_{N}\right)$ subset to AF treatment $(P<0.05$, repeated measures ANOVA followed by the Newman-Keuls post-hoc test, three donors). Moreover, downmodulation of CD27 was evident in all subsets (Figure 1b). We concluded that AF exerts a pro-differentiating effect and shortens the lifespan of memory $T$ cells independent of their $\mathrm{CD}^{+}{ }^{+}$or $\mathrm{CD}^{+}{ }^{+}$lineage.

To confirm that susceptibility to AF-induced cell death was associated with the stage of lymphocyte differentiation, we tested the effects of $\mathrm{AF}$ in stem cells (CD34 ${ }^{+}$cells) purified from human cord blood. We stained stem cells with Annexin $\mathrm{V}$ after 24 and $48 \mathrm{~h}$ of treatment with AF. The results showed that AF had no effect on the frequency of Annexin $\mathrm{V}^{+}$ cells (Supplementary Figure S1; note that CD27 is not expressed by stem cells). We conclude that the cell-deathpromoting effect of AF increases in parallel to the stage of lymphocyte differentiation.

The cytocidal and pro-differentiating effects of AF are associated with the baseline oxidative status of $\mathrm{CD}^{+}{ }^{+} \mathrm{T}$ cells. As the pro-oxidant effects of AF are well known in the literature, ${ }^{26}$ we analyzed, in sorted CD4 ${ }^{+}$T-cell subpopulations, the baseline levels of the major marker of the intracellular redox state, that is, glutathione $(\mathrm{GSH}) .{ }^{27}$ The results showed that GSH levels were lower in the memory cell subpopulations than in the $\mathrm{T}_{\mathrm{N}}$ compartment $(P<0.001$; Figure 2a). Repletion of GSH, however, did not inhibit the cytocidal and pro-differentiating effect of AF (data not shown), indicating that GSH is unlikely to be a direct target of $\mathrm{AF}$ in $\mathrm{CD}^{+}{ }^{+} \mathrm{T}$ cells.

To test whether this result could be extendable to the bulk of intracellular reactive thiols, we analyzed sorted $\mathrm{CD} 4{ }^{+} \mathrm{T}$-cell subpopulations by flow cytometry, using the ThiolTracker Violet (Invitrogen Molecular Probes, Milan, Italy) (Figure 2b). We found that the total thiol content decreased in parallel to the level of lymphocyte differentiation $(P<0.05$; Spearman's correlation test, see Figure $2 \mathrm{~b}$ ).

The thiol/selenium proteins TrxRs represent another major intracellular defense against oxidative stress. AF is a wellknown inhibitor of TrxRs and, in the present study, it was used at TrxR-inhibitory concentrations. ${ }^{28}$ To test whether inhibition of these enzymes in an AF-independent manner might replicate the effect of AF, we incubated primary $C D 4{ }^{+} \mathrm{T}$ cells with arsenic trioxide $\left(\mathrm{As}_{2} \mathrm{O}_{3}\right)$, another well-known inhibitor of TrxRs. Results showed that $\mathrm{As}_{2} \mathrm{O}_{3}$ replicates the effect of $\mathrm{AF}$ at TrxR-inhibitory concentrations (i.e., $2 \mu \mathrm{M}$; see Figure $2 \mathrm{c}$ ). $\mathrm{As}_{2} \mathrm{O}_{3}$ did not exert this effect at a concentration of $250 \mathrm{~nm}$, that is, lower than its $\mathrm{EC}_{50}$ on purified TrxRs (Lin et al. ${ }^{28}$ data not shown). We conclude that compounds that inhibit TrxRs are able to induce both pro-differentiating and cytocidal effects in human primary CD4 ${ }^{+} \mathrm{T}$ cells.

Involvement of p38 MAPK activation in AF-mediated cell death. Some of the most important signaling molecules in lymphocyte cell death and differentiation are mitogenactivated protein kinases (MAPK), a family of serine/ threonine kinases. $^{29}$ The MAPK superfamily consists of different groups, one of which includes p38 MAPK, ${ }^{30}$ the activation of which represents one of the earliest sensors of TrxR inhibition. Incubation of $\mathrm{CD}^{+}{ }^{+} \mathrm{T}$ cells with $\mathrm{AF}$ increased the phosphorylation of p38 MAPK in Tyr182 (Figure 3a). This phosphorylation could be detected at $1 \mathrm{~h}$ after treatment with $\mathrm{AF}$, and, to a lesser extent, at 6 and $24 \mathrm{~h}$ (Figure $3 \mathrm{a}$ ).

To further confirm that 38 MAPK is involved in AF-induced lymphocyte cell death and differentiation, we tested a specific inhibitor of this protein (the pyridyl-imidazole inhibitor SB203580). Results showed that SB203580 inhibited the Annexin $V$ stainability of $T$ cells induced by AF and, to a lesser extent, their differentiation (Figures $3 b-d$ ). Instead, chemical inhibition of Erk1/2, another member of the MAPK superfamily, using the PD98059 inhibitor, enhanced AF-mediated cell death (Supplementary Figure S2). We conclude that p38 MAPK is an important mediator of AF-induced cell death and differentiation, whereas the Erk1/2 MAPK family member delivers a survival signal in primary CD4 ${ }^{+} \mathrm{T}$ cells, in line with previous evidence from AF-untreated cells. ${ }^{31}$

AF decreases the mitochondrial membrane potential. To further dissect the mechanism of AF-induced apoptosis, we examined the mitochondrial membrane potential (MMP, $\Delta \psi \mathrm{m})$, a decrease of which may follow p38 MAPK activation. Changes in MMP were assessed by the fluorescence transition of the $\mathrm{JC}-1$ probe, with a change from red to green fluorescence indicating a decrease in MMP (typically observed in cells undergoing apoptosis). As shown in Figure 4, treatment with AF resulted in a decrease in MMP of $\mathrm{CD}^{+}{ }^{+} \mathrm{T}$ cells, indicating that AF-induced apoptosis involves the mitochondrial pathway.

$\mathrm{T}_{\mathrm{N}}$ and $\mathrm{T}_{\mathrm{CM}} / \mathrm{T}_{\mathrm{TM}} \mathrm{CD}^{+}$lymphocytes respond to $\mathrm{AF}$ administration activating both common and different downstream signals involved in regulating cell survival, proliferation and differentiation. To explore the correlates of susceptibility to or protection from AF-induced cell death, we analyzed, in sorted $\mathrm{CD} 4^{+} \mathrm{T}$-cell subpopulations, the AFinduced changes of an array of proteins involved in antioxidant and pro-/anti-apoptotic pathways. Protein array analysis showed that AF prompted dramatic changes in protein expression, which, in some cases, were peculiar to the different subsets analyzed (Figures $5 a-c$ ). In all longlived $\mathrm{CD}^{+}{ }^{+}$subsets, that is, $\mathrm{T}_{\mathrm{N}}, \mathrm{T}_{\mathrm{CM}}$ and $\mathrm{T}_{\mathrm{TM}}, \mathrm{AF}$ increased the levels of the pro-apoptotic factors Ask1 (S38 phosphorylated), p38 (Tyr180 phosphorylated, Figure 5b) and Bax/Bak (total, Figure $5 \mathrm{c}$ ), but decreased the expression of the apoptosis-regulating factor p53 (Figure 5c). Moreover, AF increased the levels of the lymphocyte activation and differentiation factor phospho-ZAP-70(Tyr319)/SyK(Tyr352) (Figure $5 \mathrm{c}$ ). In line with the well-known positive feedback effects induced by the presence of a specific inhibitor, ${ }^{32}$ TrxR1 and TrxR2 were also increased in all CD4 ${ }^{+}$subsets (Figure 5a). On the other hand, the mitochondrial peroxide generator, $\mathrm{Mn}^{2+}$ superoxide dismutase (MnSOD), was upregulated by AF only in the memory T-cell subsets (Figure 5a). No peculiar change was instead observed for the AF-treated $T_{N}$ subset, apart from extremely high levels of the antioxidant and anti-apoptotic enzyme TrxR2 (data not shown). As a support of the concept that susceptibility to AF-induced apoptosis increases in parallel to lymphocyte 


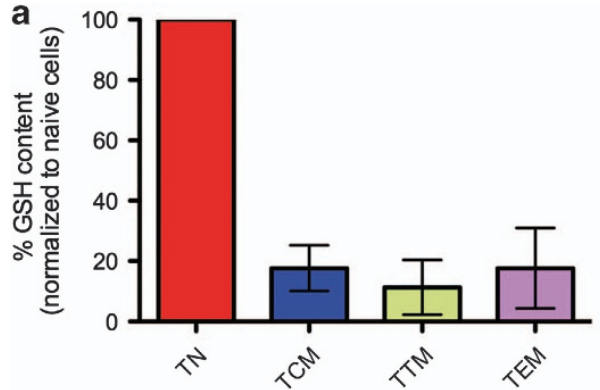

b

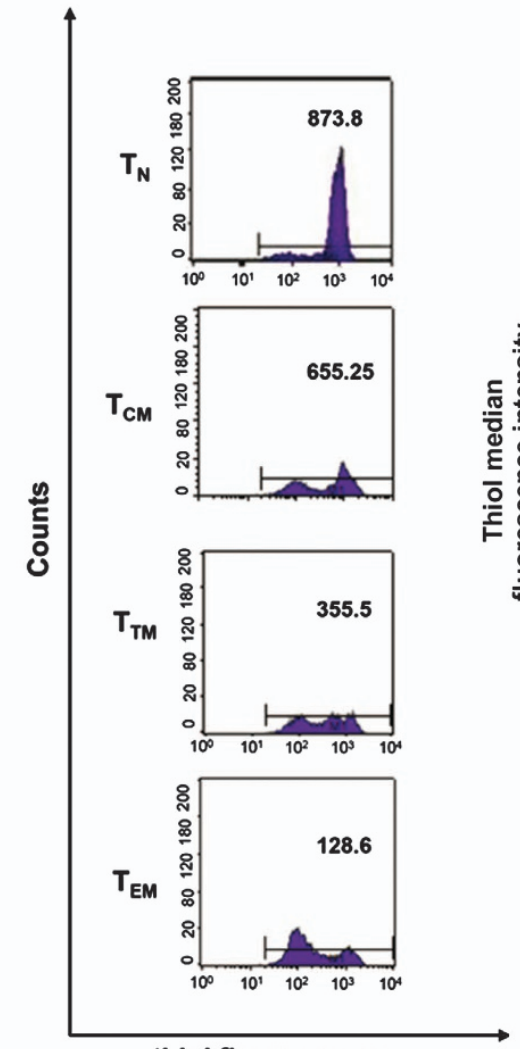

thiol fluorescence
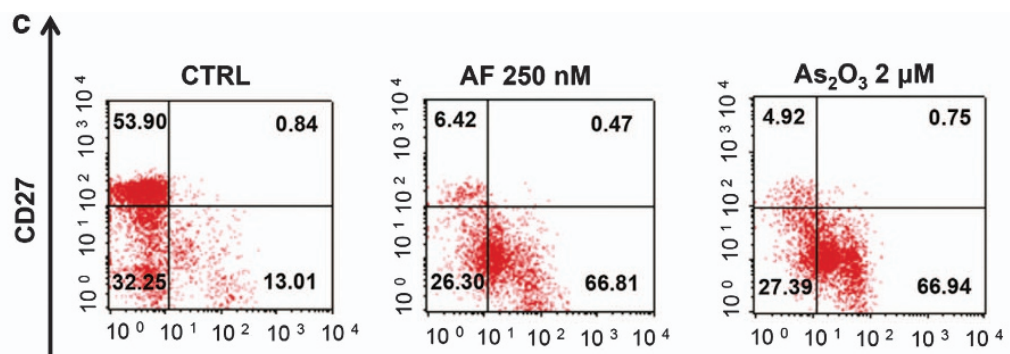

Annexin V

Figure 2 Baseline antioxidant levels in sorted $\mathrm{CD} 4^{+}$T-cell subpopulations reflect their susceptibility to AF. (a) Total GSH levels in sorted CD4 ${ }^{+} \mathrm{T}_{\text {-cell subpopulations. }}$ $\mathrm{CD}^{+}{ }^{+}$T-cell subpopulations were separated by sorting and baseline GSH levels were measured. Data points represent the means from three independent experiments normalized to $T_{N}$ cells. Data are shown as median \pm interquartile range $\left(n=3 ; P<0.001\right.$; repeated measures ANOVA). (b) Total thiol content in sorted CD4 ${ }^{+} \mathrm{T}_{\text {-cell }}$ subpopulations. The thiol content was measured, in all CD4 ${ }^{+} \mathrm{T}$-cell subpopulations, by FACS after labeling cells with ThiolTracker violet dye. The data displayed in both the dot plot and the $x, y$ graph are expressed as the median of fluorescence intensity. On the ' $x$ ' axis of the $x, y$ graph, the level of CD4 ${ }^{+}$T-cell differentiation was associated, for clarity purposes, to an increasing score ranging from 0 to $3\left(0=\mathrm{T}_{N} ; 1=\mathrm{T}_{\mathrm{CM}} ; 2=\mathrm{T}_{\mathrm{TM}} ; 3=\mathrm{T}_{\mathrm{EM}} ; P<0.05\right.$; Spearman's correlation test). (c) Replication of the effects of $\mathrm{AF}$ on $\mathrm{CD}^{+}{ }^{+} \mathrm{T}$ cells by the TrxR inhibitor arsenic trioxide $\left(\mathrm{As}_{2} \mathrm{O}_{3}\right)$. The dot plots show the effect of $\mathrm{AF}$ and $\mathrm{As}_{2} \mathrm{O}_{3}$ on total $\mathrm{CD} 4^{+} \mathrm{T}$ cells after $48 \mathrm{~h}$ of treatment, analyzed by $\mathrm{CD} 27$ ( $y$ axis) and Annexin $\mathrm{V}$ ( $x$ axis) staining. The dot plot shows data from one representative experiment out of three with similar results

differentiation, the level of the effector caspases 3 and 9 was increased in the most differentiated subsets (Figure 5c).

That $\mathrm{AF}$ also has a potential impact on reducing lymphocyte proliferation (and, hence, reservoir expansion) is shown by the fact that the cell cycle associated protein Ki67 was decreased in all three long-lived subsets (Figure $5 \mathrm{c}$ ). Whereas $\mathrm{T}_{\mathrm{CM}}$ and $\mathrm{T}_{\mathrm{TM}}$ cells reacted to AF administration also downregulating CD25, that is, the $\alpha$-chain of the receptor for interleukin-2 (IL-2), a wellknown mitogenic and anti-apoptotic cytokine, $\mathrm{T}_{\mathrm{N}}$ cells compensated the AF-induced Ki67 downregulation by upregulating CD25. These results point to different mechanisms by which the $T_{N}$ and $T_{C M} / T_{T M}$ subsets react to the AF-induced stress and that may be responsible for the different in vivo susceptibility of these cell compartments to AF-induced apoptosis. ${ }^{7}$

AF induces a burst in intracellular peroxide levels within $\mathrm{CD}^{+} \mathbf{T}$ cells. Given the ability of AF to increase the levels of MnSOD, we analyzed reactive oxygen species (ROS) following treatment with AF. To this aim, we measured, by flow cytometry, the levels of dihydrorhodamine (DHR), a compound that becomes fluorescent upon oxidation by intracellular peroxides such as hydrogen peroxide, one well-known cell-death-inducing 
a
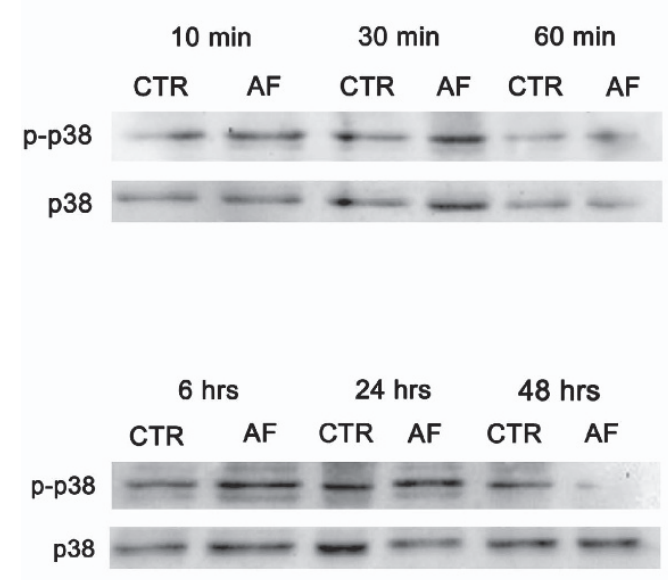

b

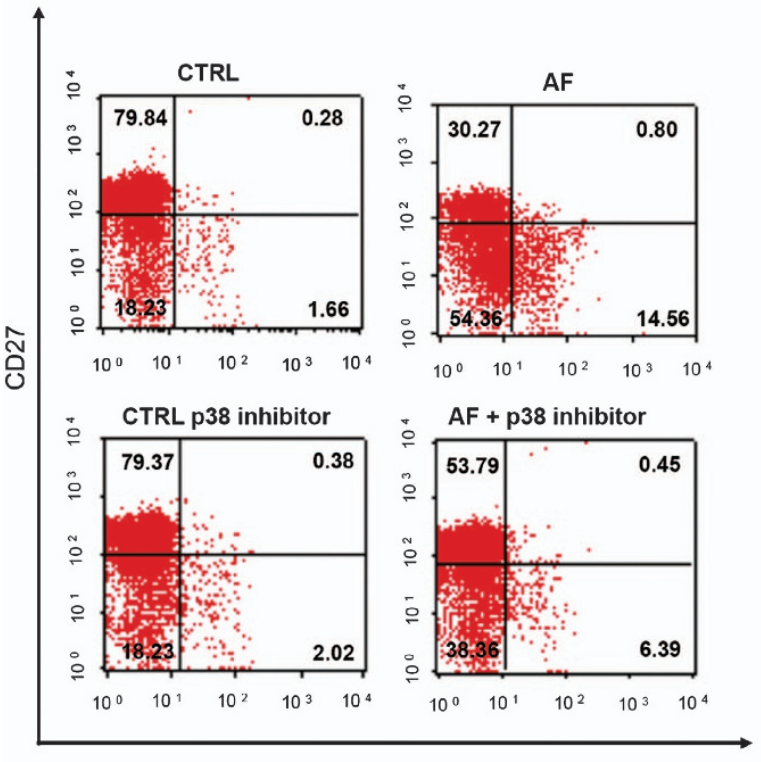

Annexin V
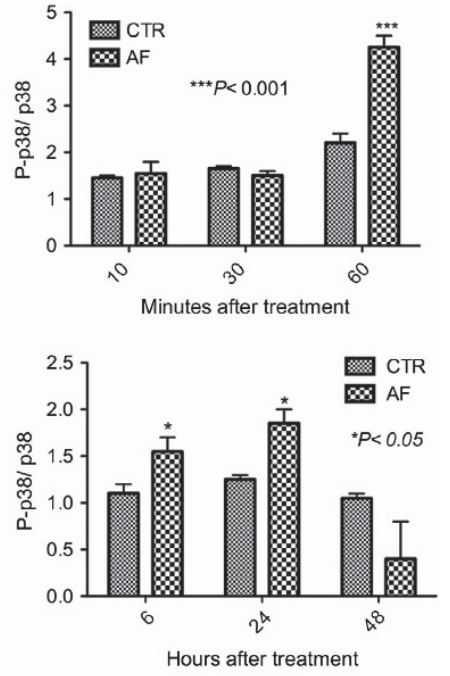

C

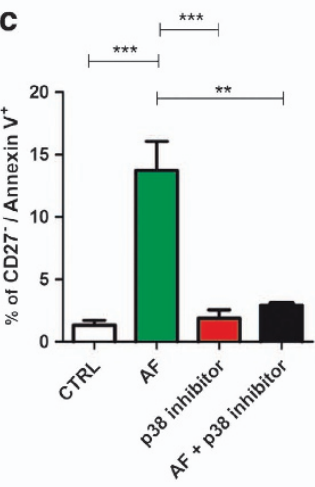

d

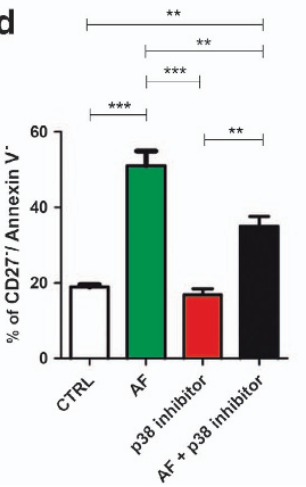

Figure 3 Role of p38 MAPK in the pro-differentiating and pro-apoptotic effects of AF. (a) Activation of p38 MAPK by AF treatment. CD4 ${ }^{+}$T cells were incubated with $250 \mathrm{~nm} \mathrm{AF} \mathrm{for} 0-48 \mathrm{~h}$. Protein extracts were prepared at the indicated time points and analyzed on western blot probed with specific antibody against the phosphorylated form of p38 MAPK (p-p38; Tyr182). Loading was controlled with an antibody against total p38 MAPK on the according blot. Respective bands were quantified using Quantity One software and relative p38 MAPK activation was calculated and normalized to the loading control. The blot is shown from one representative experiment out of the two performed. Data in densitometric analysis are graphed as means \pm s.d. of the two experiments performed (donors: $n=2 ;{ }^{*} P<0.05$; ${ }^{* * *} P<0.001$; one-tailed Student's $t$-test). (b) Effect of AF and the p38 MAPK inhibitor SB203580 on CD27 and Annexin V staining in human CD4 ${ }^{+} \mathrm{T}$ cells after $48 \mathrm{~h}$ of treatment. The dot plot shows data from one representative experiment out of three (similar results). (c) Percentages of CD27 ${ }^{-} /$Annexin $\mathrm{V}^{+} \mathrm{CD} 4^{+} \mathrm{T}$ cells after $48 \mathrm{~h}$ of treatment with $\mathrm{AF}$ and SB203580. Data are shown as means \pm s.d. ( $\mathrm{n}$ of donors $=3$; ${ }^{*} P<0.05$; ${ }^{* \star} P<0.01 ;{ }^{* \star *} P<0.001$; Newman-Keuls post-hoc test following repeated measures ANOVA and LOGIT transformation). (d) Percentages of $\mathrm{CD}^{-} 7^{-} /$Annexin $\mathrm{V}^{-} \mathrm{T}$ cells after $48 \mathrm{~h}$ of treatment. Data are shown as means \pm s.d. ( $\mathrm{n}$ of donors $=3$; ${ }^{*} P<0.05 ;{ }^{* \star} P<0.01 ;{ }^{* \star *} P<0.001$; Newman-Keuls post-hoc test following repeated measures ANOVA and LOGIT transformation)

agent. $^{33,34}$ As shown in Figure $6 a$, AF only moderately increased intracellular peroxides levels until $48 \mathrm{~h}$ of treatment, at which a major burst was observed (Figures $6 a$ and b).

It is well known that the cytocidal effects of hydrogen peroxide are mediated by ROS following its degradation through the iron-catalyzed Fenton reaction. ${ }^{35}$ In line with this view, the iron-containing drug ferroquine greatly enhanced AF-mediated cell death, although the iron compound was per se unable to carry out AF-like effects (data not shown). 


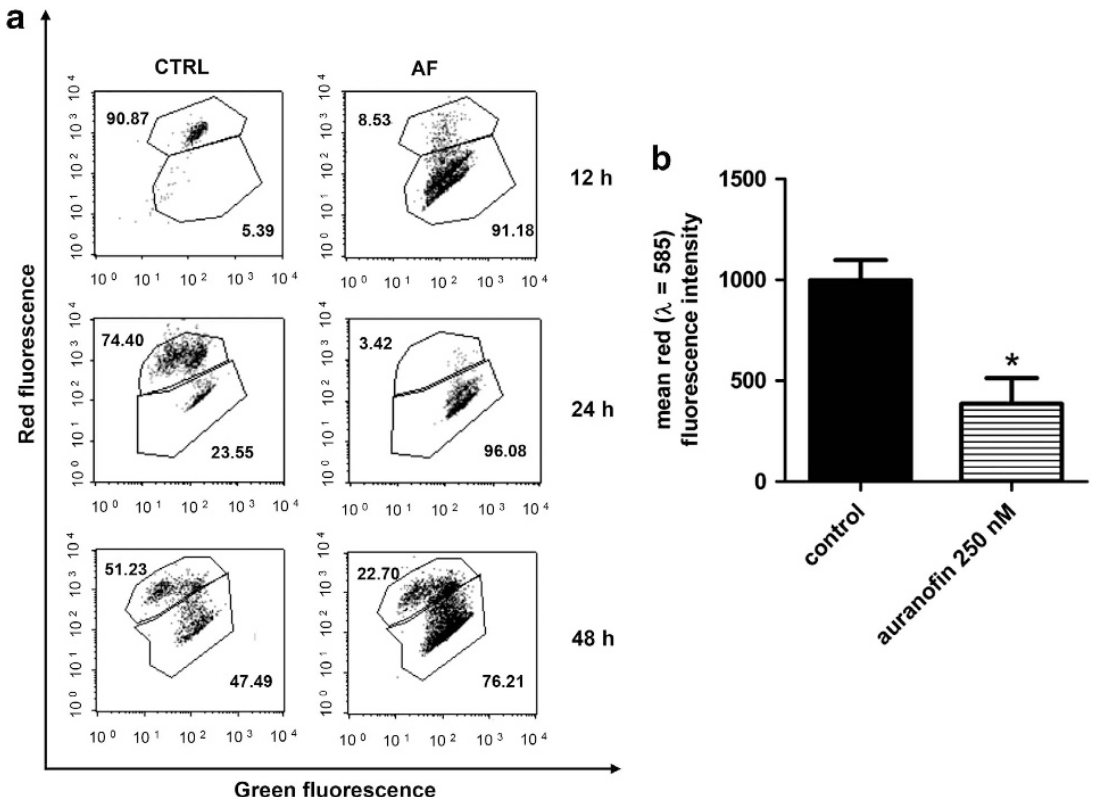

Figure 4 Analysis of MMP $(\Delta \psi \mathrm{m})$ in $\mathrm{CD}^{+}{ }^{+} \mathrm{T}$ cells after AF treatment. Cells were stimulated with AF for $12-48 \mathrm{~h}$ and stained with the JC-1 probe. After staining with JC-1, live cells display red fluorescence (high MMP), whereas apoptotic cells display intermediate or green fluorescence (low MMP). Note that the relatively high rates of cells displaying low MMP observed in the controls are in line with a spontaneous trend to undergo apoptosis in the memory compartment of non-stimulated CD4 ${ }^{+} \mathrm{T}_{\text {cells }}$ (see Figure 1). (a) Dot plots of red and green fluorescence at 12, 24 and $48 \mathrm{~h}$. (b) Histograms showing the decrease in mean red fluorescence intensity induced by auranofin at $48 \mathrm{~h}$. Data are shown as mean \pm s.d. $\left(n=4 ;{ }^{*} P<0.05\right.$; two-tailed paired Student's $t$-test)

To further test whether the cell-death-promoting effects of AF might be mediated by the production of hydrogen peroxide, we treated the $\mathrm{CD}^{+}{ }^{+} \mathrm{T}$ cells with pyruvate, that is, the principal scavenger of hydrogen peroxide (Figure 6c). Pyruvate significantly prevented AF-induced Annexin V stainability but did not inhibit downregulation of CD27 (Figures 6d and e). Interestingly, apart from showing the involvement of hydrogen peroxide in the AF-mediated apoptosis of $\mathrm{CD} 4{ }^{+} \mathrm{T}$ cells, these results show that the pro-apoptotic and pro-differentiating effects of AF can be de-coupled.

AF displays pro-differentiating effects that are not confined to CD27 downregulation. Among the panel of antigens that we used to define the stage of T-cell differentiation, AF induced downmodulation of CD27 but not of CCR7 (data not shown). CD27 ${ }^{-} \mathrm{CCR} 7^{+}$cells have been described previously, although their role in vivo is not yet known. ${ }^{8}$ To elucidate whether the pro-differentiating effect of AF was confined to downmodulation of CD27, we verified the extent of downregulation of CD28, another common marker of the long-lived phenotypes $T_{N}, T_{C M}$ and $\mathrm{T}_{\mathrm{TM}}$. We found that AF downregulated CD28 expression similarly to CD27, suggesting that AF exerts a true prodifferentiating effect in human $\mathrm{CD} 4^{+} \mathrm{T}$ cells (Supplementary Figure S3).

AF induces phenotype changes in $\mathrm{CD} 4{ }^{+} \mathrm{T}$ cells from HIV-infected patients. The pro-differentiating effects of AF were eventually confirmed in $\mathrm{CD} 4^{+} \mathrm{T}$ cells isolated from three $\mathrm{HIV}^{+}$patients under ART. Treatment of these cells with $\mathrm{AF}$ for 2 days induced a significant reduction in the frequency of the long-lived $\mathrm{T}_{\mathrm{CM}}$ cells accompanied by a relative increase in the frequency of $\mathrm{T}_{\mathrm{EM}}$ cells (Figure 7 ).
$\mathrm{AF}$, however, did not induce viral emergence from latency in $\mathrm{CD}^{+}{ }^{+} \mathrm{T}$ cells isolated from HIV-1 ${ }^{+}$individuals following 3 days of treatment (data not shown).

\section{Discussion}

We here show that AF promotes differentiation and apoptosis of the memory $\mathrm{CD}_{4}{ }^{+} \mathrm{T}$-cell subsets that encompass the HIV-1 reservoir. This potential anti-reservoir mechanism is novel and different from the currently investigated 'shock and kill' strategies for HIV reservoir elimination, in that the latter are aimed at inducing viral replication in latent viral reservoirs (which cannot be recognized by drugs or the immune system), whereas AF can shorten the lifespan of the viral reservoirs, favouring their elimination. In this regard, AF-based strategies do not present the risk of enhancing viral replication in $\mathrm{HIV}^{+}$ patients. The pro-apoptotic and pro-differentiating effects of $\mathrm{AF}$ were also observed in another cell subpopulation, the central memory $\mathrm{CD}^{+} \mathrm{T}$ cells, the expansion of which is associated with progression to AIDS. ${ }^{25}$ High proportions of memory $\mathrm{CD}^{+}{ }^{+} \mathrm{T}$ cells are also associated with anergy in SIVinfected macaques, and, therefore, their elimination by $\mathrm{AF}$ may explain the improved immune responses associated with control of viral load that we previously observed in SIVinfected macaques following suspension of AF containing therapies. ${ }^{11,}{ }^{12}$ Alternatively, it is also possible that only the pro-differentiating effect of $\mathrm{AF}$ contributed to the strong CD8-based immunity, which we observed after treatment interruption, and that death of $\mathrm{CD}^{+}{ }^{+} \mathrm{T}$ cells is a so-far inevitable by-product of this strategy.

A major finding of the present study is that the viral reservoir-harbouring $\mathrm{CD} 44^{+} \mathrm{T}_{\mathrm{CM}} / \mathrm{T}_{\mathrm{TM}}$ cells display an overall antioxidant defense lower than that of $T_{N}$ cells, thus 


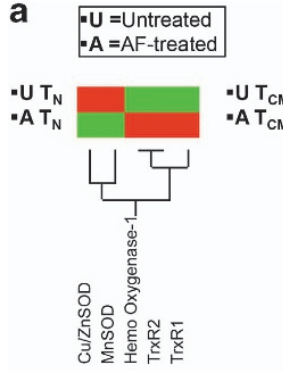

Antioxidant pathways

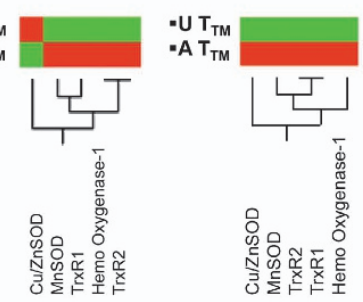

Cytokines
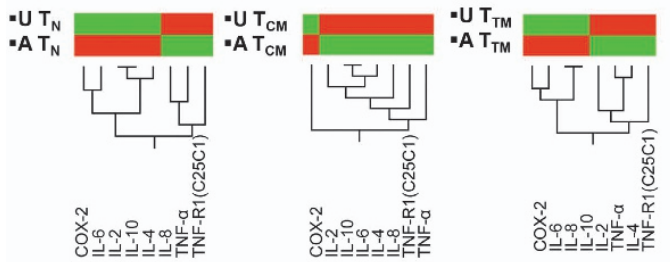

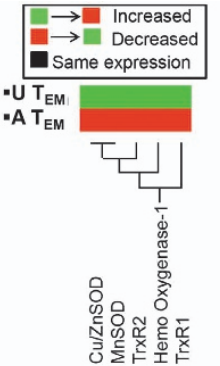

b
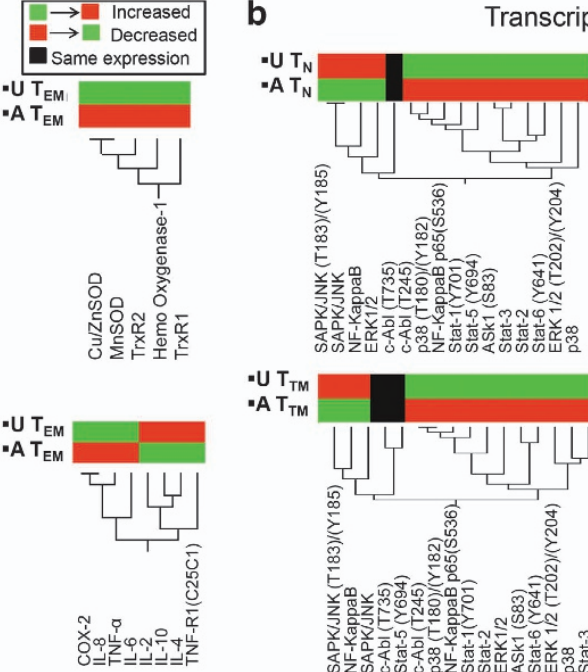

-U T $\mathrm{T}_{\mathrm{TM}}$
-A $\mathrm{T}_{\mathrm{TM}}$

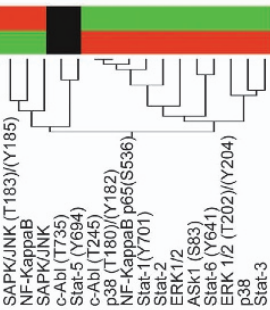

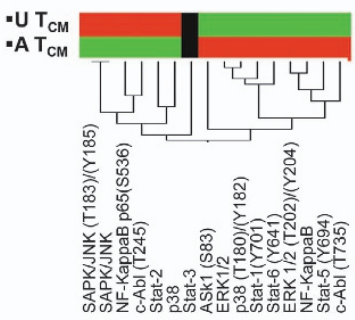

- $U T_{\text {EM }}$

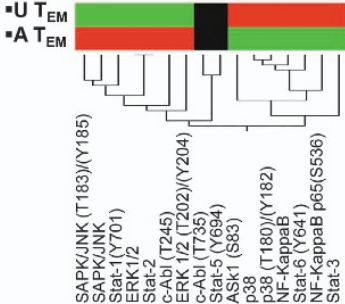

c

Cell death and survival pathways
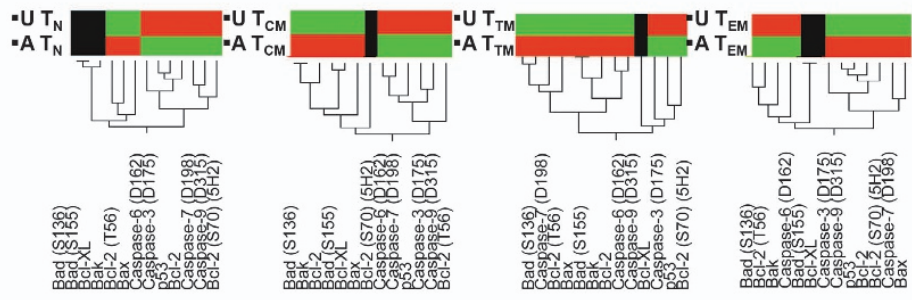

Other proteins
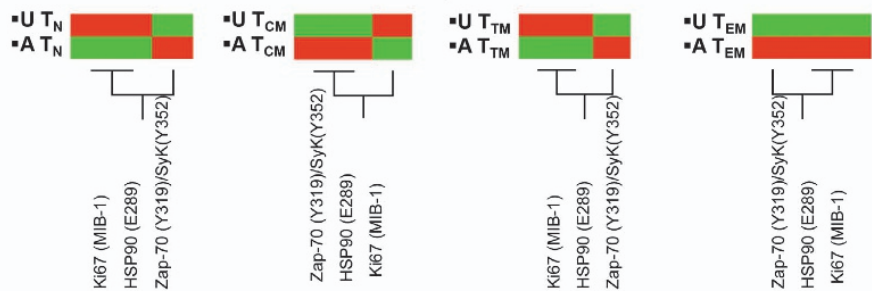

Figure 5 Protein array after AF treatment shows differential modulation of pathways involved in antioxidant responses and cell survival. (a) Antioxidant pathways and cytokines; (b) transcription factors and kinases; (c) cell death and survival pathways, and other proteins. The table was obtained by comparing the intensity level of proteins from each subpopulation of $C D 4^{+} \mathrm{T}$ cells $\left(\mathrm{T}_{\mathrm{N}}, \mathrm{T}_{\mathrm{CM}}, \mathrm{T}_{\mathrm{TM}}\right.$ and $\left.\mathrm{T}_{\mathrm{EM}}\right)$, treated with $\mathrm{AF}$ for $6 \mathrm{~h}$ or left untreated. Endpoints examined are clustered on the horizontal axis. Within the heat maps, red color represents higher levels of relative expression, black represents same levels and green represents lower levels of relative expression. The proteins are clustered by similarity of their expression profiles

uncovering an Achilles' heel exploitable for the elimination of the HIV reservoir. TrxRs are well studied intracellular targets of $\mathrm{AF}$ and, in the present study, the pro-apoptotic and prodifferentiating effects of AF could be replicated by $\mathrm{As}_{2} \mathrm{O}_{3}$, another TrxR inhibitor. We can therefore deduce that these enzymes represent important targets for viral reservoir elimination by drugs. Inhibition of these enzymes is in line with the activation of downstream molecular machineries that we observed in the present study. These include phosphorylation of Ask1 and MAP kinases, which are essential components of the oxidative stress signal transduction pathways, and have a central role in cell growth, differentiation and programmed cell death. ${ }^{34-39}$

Our data show that activation of the redox-sensitive protein p38 MAPK is associated with the pro-apoptotic activity of AF. The late increase in ROS that we observed here is also consistent with mitochondrial depolarization, shown in other studies to occur following MAPK activation. ${ }^{40-42}$ It is well known that mitochondria have an increased content of ROS that, following mitochondrial membrane depolarization, are released into the cytosol. One likely explanation behind the partially selective 'antimemory' effect of AF is that, unlike the memory subsets, $\mathrm{T}_{N}$ cells did not show AF-induced upregulation of $\mathrm{Mn}^{2+}$ SOD, an enzyme catalyzing conversion of superoxide into hydrogen peroxide. Although $\mathrm{Mn}^{2+}$ SOD may provide an initial antioxidant benefit by limiting the pools of the superoxide ion, the accumulation of its reaction product hydrogen peroxide can be deleterious in the longer term. ${ }^{43}$ In this regard, a marked pro-apoptotic effect of hydrogen peroxide on the memory T-cell pool has been previously demonstrated. ${ }^{44}$

A possible model accounting for the pro-apoptotic effect of $A F$ in $T_{C M}$ and $T_{T M}$ cells can now be reconstructed, as shown in Figures $8 \mathrm{a}$ and $\mathrm{b}$, respectively. In this model, the downstream effects are the results of a balance of pro- 


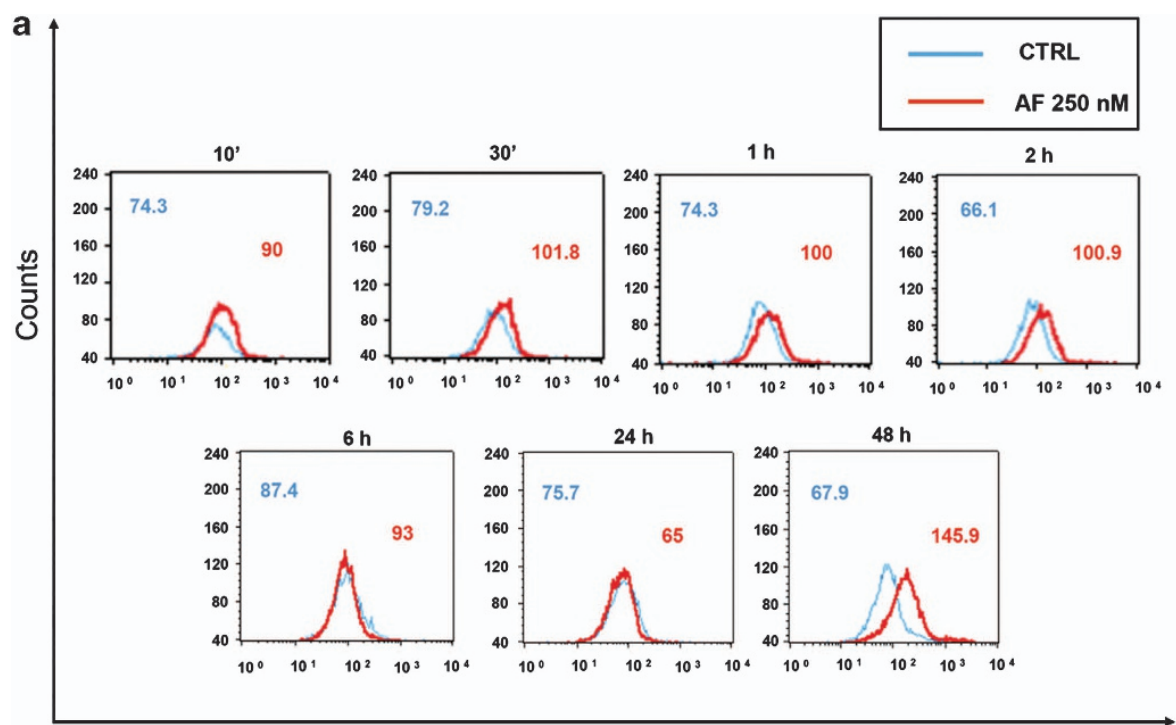

b

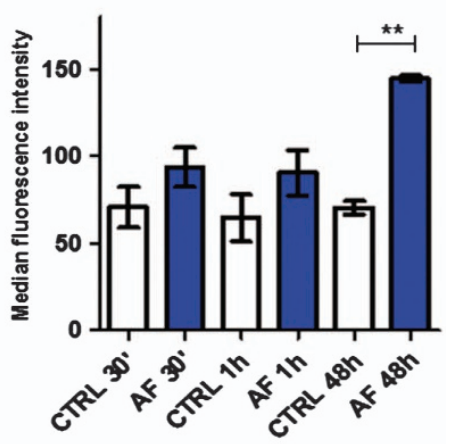

$1,2,3$, DHR fluorescence

c

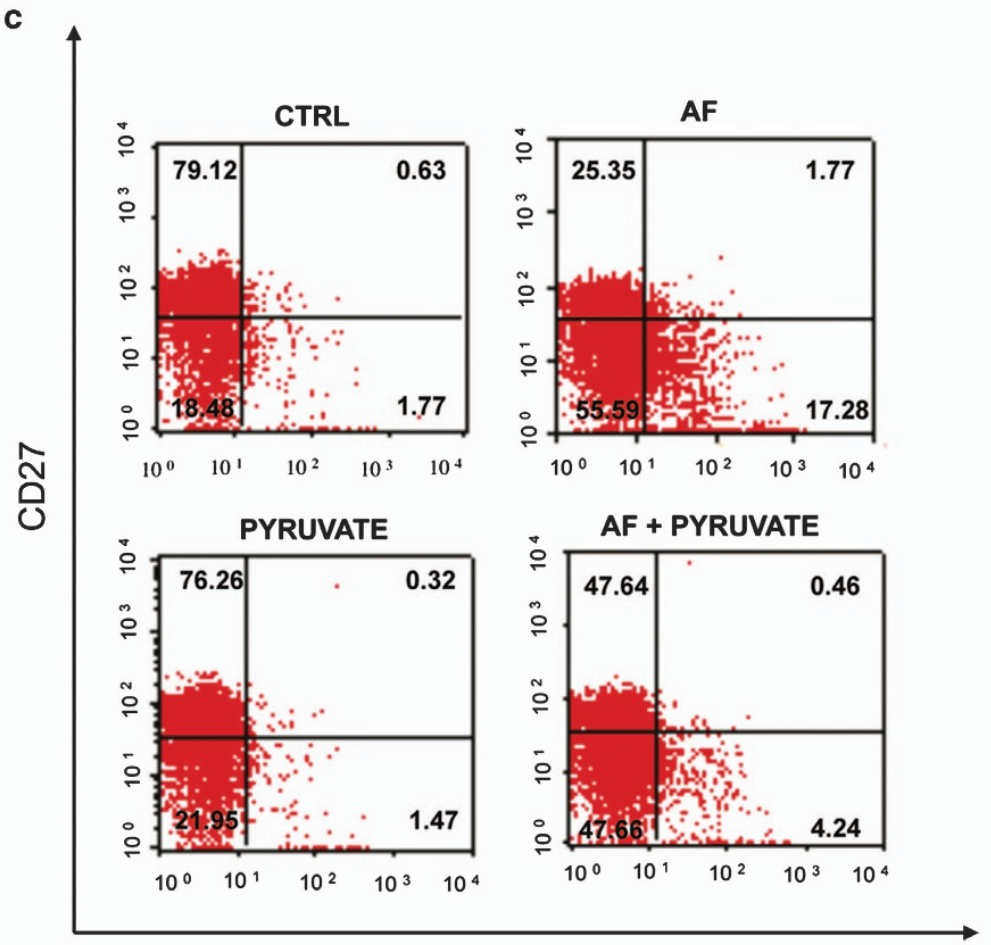

Annexin V
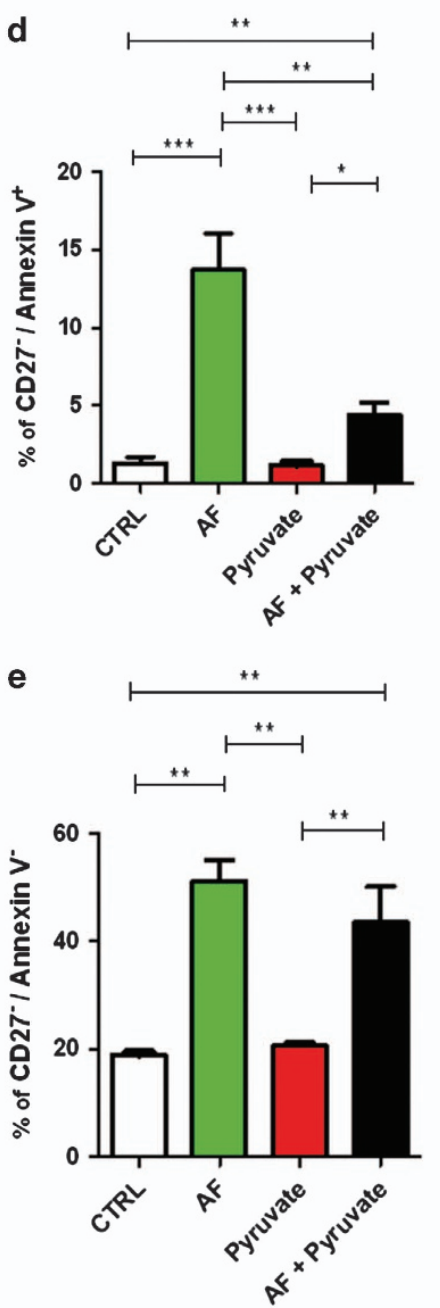

Figure 6 The role of ROS in AF-induced cell death and differentiation. (a) ROS production in CD4 ${ }^{+} \mathrm{T}$ cells. ROS content was measured by flow cytometry after labeling cells with 1,2,3 DHR. The dot plot shows ROS fluorescence in total CD4 ${ }^{+}$T cells at different time points. (b) Histograms showing median intensity of the DHR fluorescence of $\mathrm{CD}^{+} \mathrm{T}$ cells from three independent experiments. Data are shown as mean \pm s.d. ( ${ }^{* *} P<0.01$; Bonferroni's post-hoc test following two-way ANOVA). (c) Effect of pyruvate, a scavenger of peroxide, on AF-induced cell death and differentiation. Dot plots show CD27 ( $y$ axis) and Annexin V ( $x$ axis) staining of human $\mathrm{CD} 4^{+} \mathrm{T}$ cells after $48 \mathrm{~h}$ of treatment. (d) Histogram showing the percentages of CD27 ${ }^{-} /$Annexin $V^{+} T$ cells after $48 \mathrm{~h}$ of treatment from three independent experiments. Data are shown as means \pm s.d. $\left({ }^{*} P<0.05 ;{ }^{* *} P<0.01\right.$; ${ }^{* * *} P<0.001$; Newman-Keuls post-hoc test following repeated measures ANOVA and LOGIT transformation). (e) Percentages of CD27 ${ }^{-}$/Annexin $V^{-}$T cells after $48 \mathrm{~h}$ of treatment from three independent experiments. Data are shown as mean \pm s.d. ${ }^{\star} P<0.05 ;{ }^{* \star} P<0.01 ;{ }^{* * *} P<0.001 ;$ Newman-Keuls post-hoc test following repeated measures ANOVA and LOGIT transformation) 

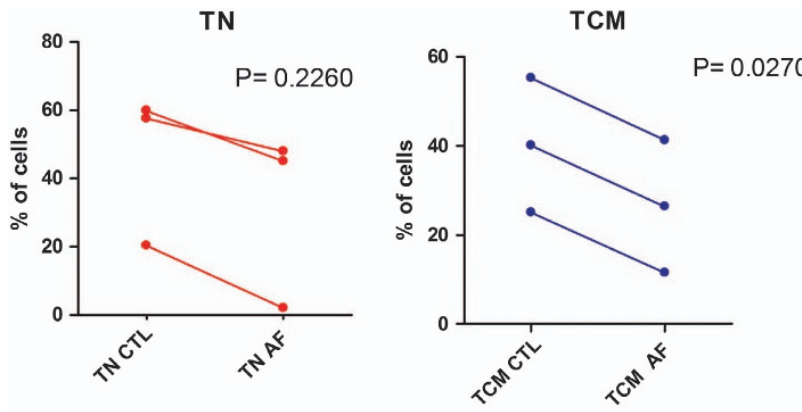

TTM
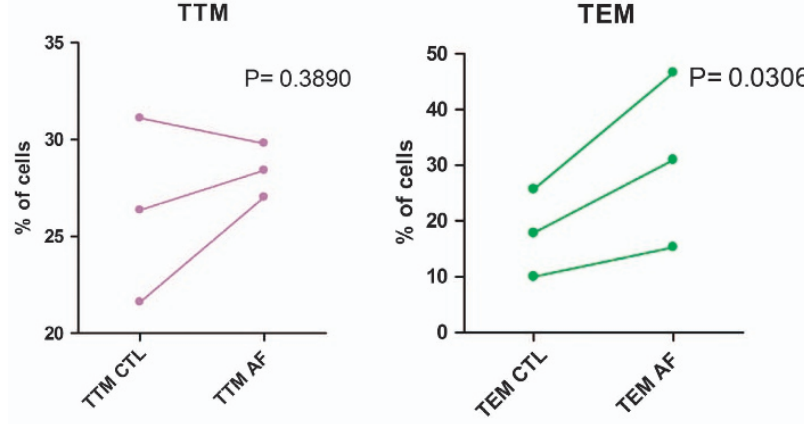

$\mathrm{CCR}^{+} \mathrm{CD} 27^{-}$

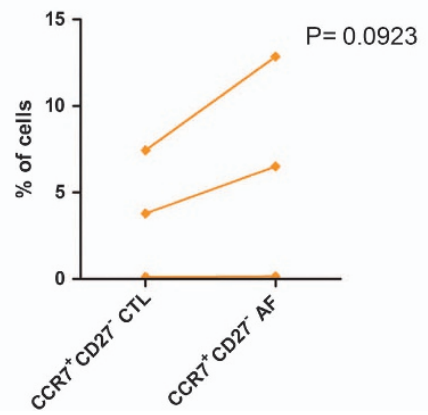

Figure 7 AF-induced phenotype changes in CD4 ${ }^{+} \mathrm{T}$ cells from HIV-infected individuals. Shown are the proportions of $\mathrm{CD}^{+}{ }^{+} \mathrm{T}$-cell subpopulations of human $\mathrm{HIV}^{+}$subjects, under ART, after 2 days of treatment with auranofin. $\mathrm{CD}^{+}{ }^{+} \mathrm{T}$-naive $\left(\mathrm{T}_{\mathrm{N}}\right.$; i.e., $\left.\mathrm{CD} 45 \mathrm{RA}{ }^{+} \mathrm{CD} 27^{+} \mathrm{CCR} 7^{+}\right), \mathrm{CD} 4^{+} \mathrm{T}_{\text {-central memory }}\left(\mathrm{T}_{\mathrm{CM}}\right.$; $\mathrm{CD} 45 \mathrm{RA}{ }^{-}$ $\left.\mathrm{CD}_{27}{ }^{+} \mathrm{CCR}^{+}\right), \mathrm{CD}^{+}{ }^{+}$-transitional memory $\left(\mathrm{T}_{\mathrm{TM}} ; \mathrm{CD}^{-} \mathrm{R} \mathrm{RA}^{-} \mathrm{CD} 27^{+}\right.$ $\mathrm{CCR}^{-}$) and $\mathrm{CD}^{+}{ }^{+}$-effector memory $\left(\mathrm{T}_{\mathrm{EM}} ; \mathrm{CD}^{-} 5 \mathrm{RA}{ }^{-} \mathrm{CD}^{-} 7^{-} \mathrm{CCR}^{-}\right)$, $\mathrm{CCR} 7^{+} \mathrm{CD} 27^{-}$. The $P$-values are shown, as obtained by paired $t$-test analysis following a LOGIT transformation to restore normality

apoptotic and pro-survival signals. AF-mediated inhibition of TrxRs would represent a sparking event in the activation of the apoptotic cascade in human primary CD4 ${ }^{+} \mathrm{T}$ cells. This event subsequently activates p38 MAPK, which becomes phosphorylated. It is known that phosphorylation of p38 MAPK is associated with a decrease in the anti-apoptotic potential of the $\mathrm{Bcl}-2$ protein. ${ }^{45,46}$ If this reconstruction is correct, p38 MAPK activation would in turn induce mitochondrial depolarization and caspase activation leading to cell death. The eventual cell death observed suggests that this pathway is able to overcome a likely AF-induced pro-survival signal emerging from our protein array analysis. This signal involves Erk1/2 and likely results in the phosphorylation of Bad in S136/ S155, hampering its dimerization with BcIXL (Figure 5c).

Our data also show that the pro-differentiating effect of $A F$ can be de-coupled from the pro-apoptotic effect. Differently from the pro-apoptotic effect, the pro-differentiating effect of $\mathrm{AF}$ is not hydrogen peroxide dependent, as evidenced by the lack of inhibition by pyruvate of the AF-induced CD27 downmodulation. The pro-differentiating pathway is likely to diverge from the pro-apoptotic pathway downstream of p38 MAPK activation. In this regard, activation of ZAP70/Syk, a pivotal mediator of lymphocyte activation and differentiation, represents a possible explanation for the pro-differentiating effects of AF. ${ }^{47}$ Ingenuity Pathway Analysis results support several possibilities for ZAP70/Syk activation as a consequence of pathways activated by AF (Supplementary Figure S4). Unfortunately, our experiments using the ZAP70/Syk inhibitor (Piceatannol, Sigma-Aldrich, St Louis, MO, USA) were hampered by the extremely high toxicity of the compound starting from $24 \mathrm{~h}$ of incubation (data not shown). The pro-differentiating effect of AF may have an important role in viral reservoir restriction in vivo, limiting the 'stem-cell-ness' of the $\mathrm{T}_{\mathrm{CM}}$ and $\mathrm{T}_{\mathrm{TM}}$ pools, and turning these cells into shortlived lymphocytes with limited in vivo persistence of the associated viral reservoir. Further investigation of these mechanisms, for example, through RNA macro-array analysis, might open new avenues for novel therapeutic strategies aimed at broader and more ambitious targets, such as complete eradication of lentiviral infections.

\section{Materials and Methods}

Cell sorting and flow cytometric analysis. Low-density mononuclear cells (less than $1,077 \mathrm{~g} / \mathrm{mL}$ ) were isolated by Ficoll-Hypaque density-gradient centrifugation (Sigma-Aldrich). Human peripheral blood mononuclear cells (PBMCs) were isolated from whole blood by Ficoll centrifugation and resuspended in RPMI-10\% fetal bovine serum (FBS). CD4 ${ }^{+} \mathrm{T}$ cells were isolated by positive selection (MACS Separation Columns, Miltenyi Biotec, Teterow, Germany). Isolated $\mathrm{CD} 4^{+} \mathrm{T}$ cells (purity: $>90 \%$ ) were stained for $20 \mathrm{~min}$ at $4{ }^{\circ} \mathrm{C}$ in MACS buffer (PBS-1,25\%FBS, 2 mM EDTA) with the following combination of antibodies: CD45RO-FITC-conjugated antibody (Becton Dickinson (BD), Franklin Lakes, NJ, USA), CD27-PE-conjugated antibody (Miltenyi Biotec, Bergisch Gladbach, Germany) and CCR7-PE Cy7-conjugated antibody (BD). Cells were washed in MACS buffer before being resuspended at $30 \times 10^{6}$ cells per $\mathrm{mL}$ in the same buffer for sorting. Cell subpopulations ( $T_{N}, T_{C M}, T_{T M}$ and $T_{E M}$; purity: $>98 \%$ ) were sorted on a BD fluorescence-activated cell sorting (FACS) Aria, (Becton-Dickinson, San Jose, CA, USA). Debris and cell doublets were gated out on the basis of physical parameters. $\mathrm{CD}_{4} \mathrm{RO}^{+}$and $\mathrm{CD} 45 \mathrm{RO}^{-}$lymphocytes were then selected after analyzing single-cell events in a FITC versus FSC plot. The gated CD45RO ${ }^{+}$ T-cell events were then plotted for CD27 versus CCR7 expression, which allows the selection of the $T_{C M}, T_{T M}$ and $T_{E M}$ subpopulations, whereas the gated $\mathrm{CD}_{5} \mathrm{RO}^{-}{ }^{-}$-cell events were plotted for $\mathrm{CD} 27$ versus $\mathrm{CCR} 7$ expression and the cells positive for both markers were sorted as $\mathrm{T}_{\mathrm{N}}$. Purity of the sorted populations was assessed by flow cytometry with a FACSCanto flow cytometer (BectonDickinson) and analyzed with the FACS Diva software (Becton-Dickinson).

Total CD4 ${ }^{+}$T cells and isolated subsets were cultured at $1 \times 10^{6}$ cells $/ \mathrm{mL}$ in RPMI supplemented with $10 \%$ FBS and IL-2. Cells were incubated with AF ( $250 \mathrm{~nm})$ and with or without different compounds aimed at enhancing/inhibiting or mimicking the effect of AF: p38 MAPK inhibitor ( $20 \mu \mathrm{m}$; SB203580 Calbiochem, La Jolla, CA, USA), Erk1/2 inhibitor ( $20 \mu \mathrm{m}, \mathrm{PD} 98059$ Calbiochem), pyruvate $(1 \mathrm{~mm}), \mathrm{As}_{2} \mathrm{O}_{3}$ $(2 \mu \mathrm{M})$ and ZAP70/Syk inhibitor (piceatannol, P0453 Sigma-Aldrich). After $48 \mathrm{~h}$ of culture, cells were collected and stained for memory and activation markers using the following combination of antibodies and reagents: CD45RO-FITC (BD) and CD27-PE (BD) in combination with Annexin V staining (Sigma-Aldrich). Cells were stained for $20 \mathrm{~min}$ at $4{ }^{\circ} \mathrm{C}$ in MACS buffer and washed in the same buffer before acquisition. 200000 events were collected during flow cytometric analysis on a FACSCalibur flow cytometer (Becton-Dickinson) and analyzed using the CellQuest Pro software (BD).

Measurement of GSH. Intracellular GSH was measured with the Glutathione assay kit (Sigma-Aldrich, Milan, Italy) according to manufacturer's instructions. The 
a

CENTRAL
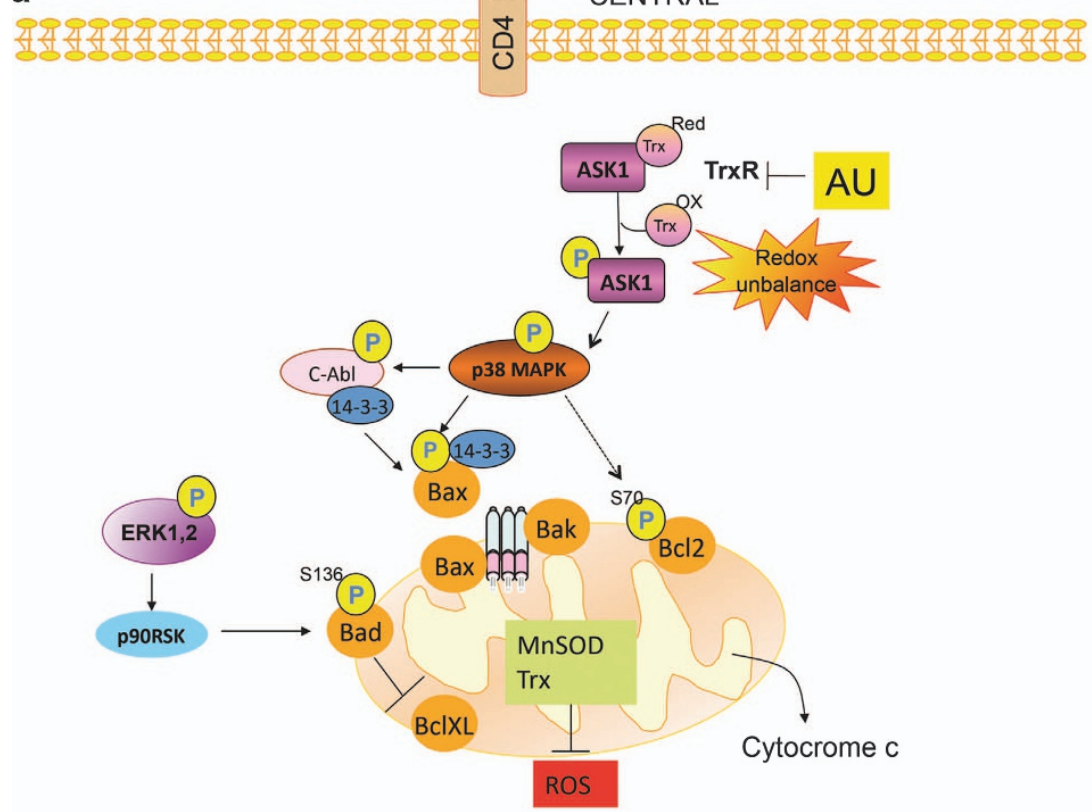

b
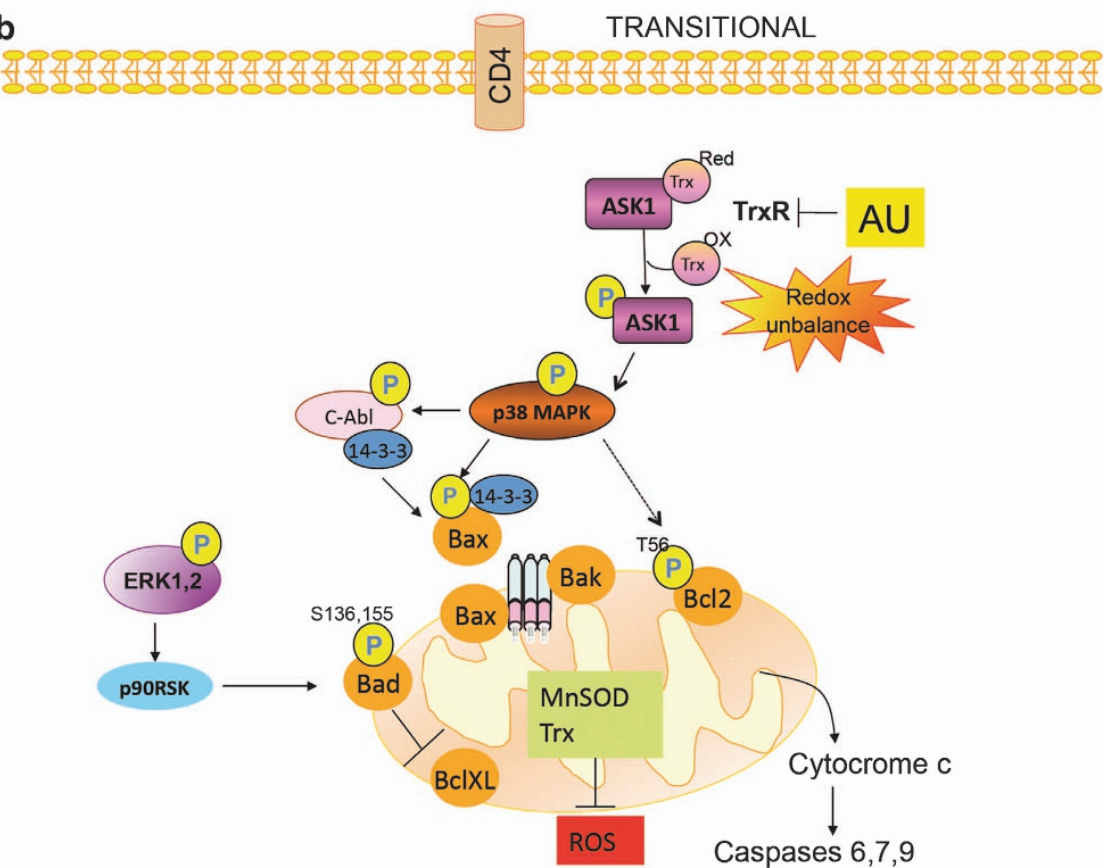

Figure 8 (a and $\mathbf{b}$ ) Proposed model of the molecular mechanisms underlying AF-induced apoptosis of human primary CD4 ${ }^{+}$central and transitional memory T cells

samples were first deproteinized with the $5 \% 5$-sulfosalicylic acid solution and their GSH content was then measured using a kinetic assay. Briefly, in this assay, catalytic amounts of GSH cause a continuous reduction of $5,5^{\prime}$-dithiobis-(2nitrobenzoic) acid (DTNB) to TNB. The quantity of TNB produced in the reaction is measured at $412 \mathrm{~nm}$, although the oxidized GS-TNB product arising from the reaction is recycled to GSH by GSH-reductase and NADPH. Values were expressed as nanomoles of GSH per milligram of protein in the original cell extract.

Measurement of thiol content. The thiol content was measured using a ThiolTracker Violet dye (10 $\mu \mathrm{m}$; T10095, Invitrogen Molecular Probes). The staining was performed by applying the dye directly to live cells ( 500000 cells) in thiol-free buffer for $30 \mathrm{~min}$ in the dark at $37^{\circ} \mathrm{C} .200000$ events were subsequently analyzed using a flow cytometer at $405 \mathrm{~nm}$ excitation as described by the manufacturer.
Detection of MMP $(\Delta \psi \mathrm{m})$. MMP was estimated by flow cytometry after staining with the JC-1 fluorescent dye (M34152, MitoProbe JC-1 Assay Kit, Life Technologies, Grand Island, NY, USA). 500000 cells were treated with AF for 12, 24 and $48 \mathrm{~h}$, harvested and then washed with cold PBS, and incubated with JC-1 solution $(2.5 \mu \mathrm{g} / \mathrm{mL})$ for $30 \mathrm{~min}$ in the dark at $37^{\circ} \mathrm{C}$. Following incubation, cells were washed twice with cold PBS and resuspended in $200 \mu \mathrm{L}$ of cold PBS. Immediately after resuspension, the fluorescence emitted by JC-1 was analyzed by flow cytometry (FACSCalibur). 200000 events were collected during flow cytometric analysis and analyzed using the CellQuest Pro software (BD). High MMP characterizes cells in the normal (live) state and favours the formation of JC-1 aggregates that predominantly yield red fluorescence $(\sim 590 \mathrm{~nm})$. Reduced MMP characterizes cells in the apoptotic state and favours the maintenance of monomeric JC-1 that yields green fluorescence $(\sim 529 \mathrm{~nm})$. Thus, a red to green switch in fluorescence indicates a decrease in the MMP. 
Western blot analysis. Cell lysates extracted from $1 \times 10^{6}$ cells were resuspended in reducing SDS sample buffer, separated on SDS-polyacrylamide gels, and blotted onto nitrocellulose membranes. The membranes were blocked with $10 \%$ nonfat dry milk in TBS-tween for $1 \mathrm{~h}$ at room temperature. The activation of p38 MAPK was detected with phospho-specific rabbit monoclonal antibody (1/ 500, Santa Cruz Biotechnology, Inc., Santa Cruz, CA, USA). After stripping of bound antibody, loading was controlled with an antibody against p38 MAPK using rabbit polyclonal antisera (1/500, Santa Cruz Biotechnology, Inc.) on the according blot, as described inref. 48. Anti-rabbit IgG horseradish-peroxidase-conjugated antibody (1/5000, Jackson ImmunoResearch Laboratories, West Grove, PA, USA) was applied for visualization. Blots were developed with an enhanced chemiluminescence system (GE Healthcare, Milan, Italy). Respective bands were quantified using Quantity One software (Bio Rad Laboratories, Hercules, CA, USA), and relative p38 MAPK activation was calculated and normalized to the loading control.

Reverse phase protein microarray analysis. Samples were printed on glass-backed nitrocellulose array slides using an Aushon 2470 arrayer (Aushon BioSystems, Burlington, MA, USA) equipped with $350 \mu \mathrm{m}$ pins as previously described. ${ }^{49}$ Sample lysates were printed on 50 nitrocellulose slides and subjected to reverse phase protein microarray analysis (RPMA). Each sample was printed in triplicate. Slides 15 and 25 were then stained with Sypro Ruby Protein Blot Stain (Molecular Probes, Eugene, OR, USA) and visualized with NovaRay Image Acquisition Software (Alpha Innotech, San Leandro, CA, USA) to determine the total protein concentration. Before antibody staining, the slides were treated with Reblot antibody stripping solution (Chemicon, Temecula, CA, USA) and incubated for $5 \mathrm{~h}$ at room temperature in blocking solution with constant shaking. Blocked slides were stained with 43 different antibodies targeting total and phosphorylated proteins using an automated stainer (Dako Cytomation, Carpinteria, CA, USA). Each antibody was subjected to rigorous validation for single band specificity at the correct molecular weight (MW) by western blotting along with the use of appropriate ligand-induction controls for phospho-specific antibodies. Catalyzed Signal Amplification System kit (Dako Cytomation) and fluorescent IRDye 680 Streptavidin (LI-COR, Lincoln, NE, USA) were used as detection system. Stained slides were scanned with NovaRay Image Acquisition Software (Alpha Innotech).

Acquired images of each slide were analyzed using MicroVigene software (Vigenetech, Carlisle, MA, USA), which finds spots, performs local background subtraction, averages replicates and normalizes each sample for the total protein value. Normalization between slides was performed using control cell lysate printed on each slide as a bridging case (Supplementary Figure S5).

Systems biology. Ingenuity Pathway Analysis (IPA7.0, Ingenuity System, http://www.ingenuity.com/) was used to establish physical and/or functional interactions among proteins found either upregulated or downregulated in AF-induced $\mathrm{CD}^{+}{ }^{+} \mathrm{T}$-cell subpopulations $\left(\mathrm{T}_{\mathrm{N}}, \mathrm{T}_{\mathrm{CM}}, \mathrm{T}_{\mathrm{TM}}\right.$ and $\left.\mathrm{T}_{\mathrm{EM}}\right)$.

Cell separation and isolation of $\mathrm{CD}^{+}{ }^{+}$T-cell subsets from $\mathrm{HIV}^{+}$ subjects by cell sorting. PBMCs from $\mathrm{HIV}^{+}$subjects were isolated from whole blood by density gradient centrifugation (Ficoll) and resuspended in RPMI/ $10 \%$ FBS. Total CD4 ${ }^{+}$T cells were isolated by negative selection on a Robosep (Stemcell-Human CD4 $+\mathrm{T}$ cell enrichment kit). Isolated $\mathrm{CD} 4^{+} \mathrm{T}$ cells (more than $90 \%$ pure, as determined by flow cytometry) from $\mathrm{HIV}^{+}$subjects were then sorted on an ARIA II (BD Biosciences) into $\mathrm{T}_{\mathrm{N}}\left(\mathrm{CD} 45 \mathrm{RA}{ }^{+} \mathrm{CD} 27^{+} \mathrm{CCR} 7^{+}\right)$, $\mathrm{T}_{\mathrm{CM}}\left(\mathrm{CD} 45 \mathrm{RA}^{-} \mathrm{CD}_{27}{ }^{+} \mathrm{CCR}^{+}\right), \mathrm{T}_{\mathrm{TM}}\left(\mathrm{CD} 45 \mathrm{RA}{ }^{-} \mathrm{CD} 27^{+} \mathrm{CCR}^{-}\right)$and $\mathrm{T}_{\mathrm{EM}}$ $\left(\mathrm{CD} 45 \mathrm{RA}^{+} \mathrm{CD}^{-} 7^{-} \mathrm{CCR}^{-}\right.$) using the following combination of antibodies: CD3-PB, CD4-A700, CD45RA-APC Cy7, CD27-PE, CCR7-PE Cy7 and Vivid-AmCyan (Invitrogen Life Technologies, Carlsbad, CA, USA). Sorted subsets were more than $98 \%$ pure.

Cell culture. Total $\mathrm{CD}^{+}{ }^{+} \mathrm{T}$ cells or isolated subsets, obtained from $\mathrm{HIV}^{+}$subjects, were cultured from 1 to $5 \times 10^{6}$ cells/mL in RPMl completed with $10 \%$ FBS for 3 to 6 days in the presence or absence of increasing concentrations of AF ranging from 0 to $500 \mathrm{nM}$.

Reactivation assays and HIV-1 viral RNA quantification. The virus was pelleted by centrifugation for $60 \mathrm{~min}$ at 17000 r.p.m. at $4{ }^{\circ} \mathrm{C}$. To generate the standard curve, a sample of titer-known $\mathrm{ACH} 2$ virus was pelleted in the same run. After the centrifugation, total viral RNA was extracted with the QIAamp viral RNA extraction kit from Qiagen (Crawley, UK) according to the manufacturer's instructions. Briefly, samples were lysed under highly denaturing conditions to inactivate RNases. Alcohol was added and lysates loaded onto the QIAamp spin column. Wash buffers were used to remove impurities and pure, ready-to-use RNA was then eluted in $60 \mu \mathrm{L}$ of low-salt buffer (supplied with the kit). The RNA solution was stored at $-80^{\circ} \mathrm{C}$ until use.

The purified RNA was then used as a matrix for a two-step quantitative real-time reverse transcription-PCR (RT-PCR followed by qRT-PCR). For each sample, a minimum of two independent replicates (separate wells) were performed, including the ACH2 RNA sample as a standard ranging from 300000 copies to 3 copies.

Reverse transcription (RT-PCR): Total viral RNA (17 $\mu \mathrm{L})$ was first treated with $1 \mathrm{U}$ DNase in DNase I reaction buffer $1 \times$ for $10 \mathrm{~min}$ at $25^{\circ} \mathrm{C}$. The DNase was inactivated with $1 \mu \mathrm{L} 25 \mathrm{~mm}$ EDTA for $10 \mathrm{~min}$ at $65^{\circ} \mathrm{C}$. Total viral RNA was then reverse-transcribed into complementary DNA for qPCR analysis. RT-PCR was performed in $50 \mu \mathrm{L}$ of solution containing $22 \mu \mathrm{L}$ of DNase-treated RNA, $0.5 \mu \mathrm{L}$ of each gag gene-specific primers (50 $\mu \mathrm{m}$ each), LM667 (5'-ATG CCA CGT AAG CGA AAC TCT GGC TAA CTA GGG AAC CCA CTG-3') and GagR (5'-AGC TCC CTG CTT GCC CAT A-3'), $2 \mu$ L of Superscript III RT/Platinum Taq mix and $1 \times$ Reaction mix (RT-PCR One Step kit - Invitrogen) in a final $50 \mu \mathrm{L}$ volume. No-template samples were used as negative controls. The running conditions were as follows: reverse transcription $30 \mathrm{~min}$ at $50^{\circ} \mathrm{C}$, denaturation $2 \mathrm{~min}$ at $94^{\circ} \mathrm{C}$ followed by 20 cycles of $94^{\circ} \mathrm{C}$ for $15 \mathrm{sec}$ (denaturation), $62^{\circ} \mathrm{C}$ for $30 \mathrm{~s}$ (annealing) and $68^{\circ} \mathrm{C}$ for $1 \mathrm{~min}$ (extension). The reaction was achieved by a final elongation at $68^{\circ} \mathrm{C}$ for $5 \mathrm{~min}$ before cooling gradually to $4^{\circ} \mathrm{C}$. The cDNAs were diluted 10-fold with DNase-RNasefree water, then subjected to quantitative real-time PCR analysis.

Quantitative real-time PCR: Experiments were performed with a LightCycler Carousel-based system (Roche, Penzberg, Germany). $\mathrm{H}_{2} \mathrm{O}$ was included as a notemplate control. All reactions were carried out in $20 \mu \mathrm{L}$ of reaction mixtures containing $6.4 \mu \mathrm{L}$ of cDNAs, $0.3 \mu \mathrm{L}$ of Taq DNA polymerase (Invitrogen), $1 \mathrm{X}$ Jumpstart mix (Sigma), $1.8 \mu \mathrm{L} \mathrm{MgCl} 25 \mathrm{~mm}, 0.25 \mu \mathrm{L}$ of each gag gene-specific primers (100 $\mu \mathrm{m}$ each), Lambda T (5'-ATG CCA CGT AAG CGA AAC T-3') and A55M (5'-GCT AGA GAT TTT CCA CAC TGA CTA A-3'), $0.5 \mu \mathrm{L}$ each hybridization probes ( $8 \mu \mathrm{m}$ each) LTR-LC (LCred640-5'-CAC TCA AGG CAA GCT TTA TTG AGG C-3'-Phosphate) and LTR-FL (5'-CAC AAC AGA CGG GCA CAC ACT ACT TGA-3'-Fluorescein). The running conditions were as follows: $4 \mathrm{~min}$ at $95^{\circ} \mathrm{C}$, followed by 50 cycles of $95^{\circ} \mathrm{C}$ for $10 \mathrm{sec}$ (denaturation), $60^{\circ} \mathrm{C}$ for $10 \mathrm{sec}$ (annealing) and $72^{\circ} \mathrm{C}$ for $9 \sec$ (extension). Following the PCR reaction, melting curve analysis was performed to control amplification specificity by measuring the fluorescence intensity across the temperature interval from $45^{\circ} \mathrm{C}$ to $95^{\circ} \mathrm{C}$. The absence of nonspecific products or primer dimers was indicated by observation of a single melting peak in melting curve analysis.

Statistical analyses. Statistical analyses were conducted using GraphPad Prism, v5.0 (GraphPad software, La Jolla, CA, USA), unless otherwise specified. Correlation between two variables was analyzed using Spearman's correlation coefficients (r). Differences between variables were analyzed using parametric tests such as $t$-tests, or, in case of multiple comparisons, one- or two-way analysis of variance (ANOVA) followed by an appropriate post-hoc test. Paired or repeated measures tests were adopted for matched observational data points. An appropriate transformation such as the LOGIT transformation of percentage values was done to restore normality, where necessary. A $P$-value $<0.05$ was considered to be statistically significant.

\section{Conflict of Interest}

The Istituto Superiore di Sanità has requested patent rights on the use of auranofin for treatment of HIV/AIDS.The authors declare no conflict of interest.

Acknowledgements. This work was supported by the Istituto Superiore di Sanità (501/P3) and, partially, by the Italian Ministry of Instruction, Universities and Research (PON01-01802). We thank Jonathan Karn, Case Western University, Cleveland, OH, USA, for helpful discussion; Mauro Biffoni, Istituto Superiore di Sanità, Rome, Italy, for excellent technical consultancy; Agnese D'Angiò, Istituto Superiore di Sanità, Rome, Italy, for technical support; and Judy Coates, Mintek, Randburg, South Africa, and Christophe Biot, Université Lille, Lille, France, for gently donating the purified powders of AF and ferroquine, respectively. 


\section{Author contributions}

AS, ATP and EG conceived the study. AS designed the experiments, analyzed the data, drafted the manuscript and directed the study; ATP and EG codirected the study; $\mathrm{BC}$ conducted the in vitro experiments and participated at data analysis, manuscript drafting, experimental design and project coordination; RS conducted in vitro experiments on intracellular signaling, contributed to data analysis and interpretation of the molecular mechanism; SDF and NC conducted the experimental design and the ex vivo analyses of cells from $\mathrm{HIV}^{+}$patients; ILS and SN contributed preliminary work and ideas on which this report is based; $\mathrm{DA}$ and $\mathrm{BD}$ (from Dr. Jonathan Karn's laboratory) conduced the Ingenuity Pathway Analysis; $\mathrm{AB}$ conducted the cell sorting; EP cultivated the stem cells; $\mathrm{DL}, \mathrm{LL}$ and PEIII conducted the RPMA.

1. Badley AD, Sainski A, Wightman F, Lewin SR. Altering cell death pathways as an approach to cure HIV infection. Cell Death Dis 2013; 4: 718.

2. Lafeuillade A. Eliminating the HIV reservoir. Curr HIV/AIDS Rep 2012; 9; 121-131.

3. Remoli AL, Marsili G, Battistini A, Sgarbanti M. The development of immune-modulating compounds to disrupt HIV latency. Cytokine Growth Factor Rev 2012; 23: 159-172.

4. Monforte AD, Svicher V, Nozza S, Lazzarin A, Marchetti G, Perno CF. Highlights on HIV eradication in 2013. AIDS 2013 [Epub ahead of print].

5. Savarino A, Garaci $E$. Therapeutic imprinting of the immune system: towards a remission of AIDS in primates? Retrovirology 2012; 9: 75.

6. Palmer S, Josefsson L, Coffin JM. HIV reservoirs and the possibility of a cure for HIV infection. J Intern Med 2011; 270: 550-560.

7. Lewis MG, Dafonseca S, Chomont N, Palamara AT, Tardugno M, Mai A et al. Gold drug auranofin restricts the viral reservoir in the monkey AIDS model and induces containment of viral load following ART suspension. AIDS 2011; 25: $1347-1356$.

8. Chomont N, El-Far M, Ancuta P, Trautmann L, Procopio FA, Yassine-Diab B et al. HIV reservoir size and persistence are driven by $\mathrm{T}$ cell survival and homeostatic proliferation. Nat Med 2009; 15: 893-900.

9. Chomont N, DaFonseca S, Vandergeeten C, Ancuta P, Sékaly RP. Maintenance of CD4 + T-cell memory and HIV persistence: keeping memory, keeping HIV. Curr Opin HIV AIDS 2011; 6: 30-36.

10. Finzi D, Blankson J, Siliciano JD, Margolick JB, Chadwick K, Pierson T et al. Latent infection of CD4 $+\mathrm{T}$ cells provides a mechanism for lifelong persistence of HIV-1, even in patients on effective combination therapy. Nat Med 1999; 5: 512-517.

11. Shytaj IL, Norelli S, Chirullo B, Della Corte A, Collins M, Yalley-Ogunro J et al. A highly intensified ART regimen induces long-term viral suppression and restriction of the viral reservoir in a simian AIDS model. PLoS Pathog 2012; 8: e1002774.

12. Shytaj IL, Chirullo B, Wagner W, Ferrari MG, Sgarbanti R, Corte AD et al. Investigational treatment suspension and enhanced cell-mediated immunity at rebound followed by drugfree remission of simian AIDS. Retrovirology 2013; 10: 71.

13. Eisler R. Chrysotherapy: a synoptic review. Inflamm Res 2003; 52: 487-501.

14. Friker SP. Medical uses of gold compounds: past, present and future. Gold Bull 1996; 29: 53-59.

15. Sutton BM. Gold compound for rheumatoid arthritis. Gold Bull 1986; 19: 15-16.

16. Kean WF, Hart L, Buchanan WW. Auranofin. Br J Rheumatol 1997; 36: 560-572.

17. Hashimoto K, Whitehurst CE, Lipsky PE. Synergistic inhibition of $T$ cell proliferation by gold sodium thiomalate and auranofin. J Rheumatol 1994; 21: 1020-1026.

18. Han S, Kim K, Kim H, Kwon J, Lee YH, Lee CK et al. Auranofin inhibits overproduction of pro-inflammatory cytokines, cyclooxygenase expression and PGE2 production in macrophages. Arch Pharm Res 2008; 31: 67-74.

19. Kim TS, Kang BY, Lee MH, Choe YK, Hwang SY. Inhibition of interleukin-12 production by auranofin, an anti-rheumatic gold compound, deviates CD4(R) T cells from the Th1 to the Th2 pathway. Br J Pharmacol 2001; 134: 571-578.

20. Gromer S, Wissing J, Behne D, Ashman K, Schirmer RH, Flohé L et al. A hypothesis on the catalytic mechanism of the selenoenzyme thioredoxin reductase. Biochem $J$ 1998; 332 : 591-592.

21. Rigobello MP, Scutari G, Boscolo R, Bindoli A. Induction of mitochondrial permeability transition by auranofin, a gold(I)-phosphine derivative. Br J Pharmacol 2002; 136: 1162-1168.

22. Rigobello MP, Folda A, Dani B, Menabo R, Scutari G, Bindoli A. Gold(I) complexes determine apoptosis with limited oxidative stress in Jurkat T cells. Eur J Pharmacol 2008; 582: $26-34$

23. Cox AG, Brown KK, Arner ES, Hampton MB. The thioredoxin reductase inhibitor auranofin triggers apoptosis through a Bax/Bak-dependent process that involves peroxiredoxin 3 oxidation. Biochem Pharmacol 2008; 76: 1097-1109.

24. López M, Soriano V, Peris-Pertusa A, Rallón N, Restrepo C, Benito JM. Elite controllers display higher activation on central memory CD8 T cells than HIV patients successfully on HAART. AIDS Res Hum Retroviruses 2011; 27: 157-165.
25. Hazenberg MD, Otto SA, van Benthem BH, Roos MT, Coutinho RA, Lange JM et al. Persistent immune activation in HIV-1 infection is associated with progression to AIDS. AIDS 2003; 17: 1881-1888.

26. Liu C, Liu Z, Li M, Li X, Wong YS, Ngai SM et al. Enhancement of auranofin-induced apoptosis in MCF-7 human breast cells by selenocystine, a synergistic inhibitor of thioredoxin reductase. PLoS One 2013; 8: e53945.

27. Sies H. Glutathione and its role in cellular functions. Free Radic Biol Med 1999; 27: 916-921.

28. Lin S, Del Razo LM, Styblo M, Wang C, Cullen WR, Thomas DJ. Arsenicals inhibit thioredoxin reductase in cultured rat hepatocytes. Chem Res Toxicol 2001; 14: 305-311.

29. McCubrey JA, Lahair MM, Franklin RA. Reactive oxygen species-induced activation of the MAP kinase signaling pathways. Antioxid Redox Signal 2006; 8: 1775-1789.

30. Cobb MH. MAP kinase pathways. Prog Biophys Mol Biol 1999; 71: 479-500.

31. Sugawara T, Moriguchi T, Nishida E, Takahama Y. Differential roles of ERK and p38 MAP kinase pathways in positive and negative selection of T lymphocytes. Immunity 1998; 9: 565-574.

32. Nordberg J, Arnér ES. Reactive oxygen species, antioxidants, and the mammalian thioredoxin system. Free Radic Biol Med 2001; 31: 1287-1312.

33. Wardman P. Fluorescent and luminescent probes for measurement of oxidative and nitrosative species in cells and tissues: progress, pitfalls, and prospects. Free Radic Biol Med 2007; 43: 995-1022.

34. Filomeni G, Piccirillo S, Rotilio G, Ciriolo MR. p38 MAPK and ERK1/2 dictate cell death/ survival response to different pro-oxidant stimuli via p53 and Nrf2 in neuroblastoma cells SH-SY5Y. Biochem Pharmacol 2012; 83: 1349-1357.

35. Fenton HJH. Oxidation of tartaric acid in presence of iron. J Chem Soc 1894; 65: 899-910.

36. Cobb MH, Goldsmith EJ. How MAP kinases are regulated. J Biol Chem 1995; 270 14843-14846.

37. Karin M. The regulation of AP-1 activity by mitogen-activated protein kinases. J Biol Chem 1995; 270: 16483-16486.

38. Ohno K, Han J. The p38 signal transduction pathway activation and function. Cell Signal 2000; 12: 1-13.

39. Filomeni G, Ciriolo MR. Redox control of apoptosis: an update. Antioxid Redox Signal 2006; 8: 2187-2192.

40. Chang KC, Hsu CC, Liu SH, Su CC, Yen CC, Lee MJ et al. Cadmium induces apoptosis in pancreatic $\beta$-cells through a mitochondria-dependent pathway: the role of oxidative stress-mediated c-Jun N-terminal kinase activation. PLOS One 2013; 8: e54374.

41. Zhao WX, Tang SS, Jin X, Zhang CM, Zhang T, Wang CC et al. Olaquindox-induced apoptosis is suppressed through p38 MAPK and ROS-mediated JNK pathways in HepG2 cells. Cell Biol Toxicol 2013; 29: 229-238.

42. Kim IS, Jin JY, Lee IH, Park SJ. Auranofin induces apoptosis and when combined with retinoic acid enhances differentiation of acute promyelocytic leukaemia cells in vitro. $\mathrm{Br} J$ Pharmacol 2004; 142: 749-755.

43. Buettner GR. Superoxide dismutase in redox biology: the roles of superoxide and hydrogen peroxide. Anticancer Agents Med Chem 2011; 11: 341-346.

44. Takahashi A, Hanson MG, Norell HR, Havelka AM, Kono K, Malmberg KJ et al. Preferential cell death of CD8 + effector memory (CCR7-CD45RA-) T cells by hydrogen peroxideinduced oxidative stress. J Immunol 2005; 174: 6080-6087.

45. De Chiara G, Marcocci ME, Torcia M, Lucibello M, Rosini P, Bonini P. Bcl-2 Phosphorylation by p38 MAPK: identification of target sites and biologic consequences. J Biol Chem 2006; 281: 21353-21361.

46. Farley N, Pedraza-Alva G, Serrano-Gomez D, Nagaleekar V, Aronshtam A, Krahl T. p38 mitogen-activated protein kinase mediates the Fas-induced mitochondrial death pathway in CD8 + T cells. Mol Cell Biol 2006; 26: 2118-2129.

47. Weiss A, Littman DR. Signal transduction by lymphocyte antigen receptors. Cell 1994; 76 : 263-274.

48. Marjuki H, Alam MI, Ehrhardt C, Wagner R, Planz O, Klenk HD et al. Membrane accumulation of influenza $A$ virus hemagglutinin triggers nuclear export of the viral genome via protein kinase Calpha-mediated activation of ERK signaling. J Biol Chem 2006; 281: 16707-16715.

49. Espina V, Edmiston KH, Heiby M, Pierobon M, Sciro M, Merritt B et al. A portrait of tissue phosphoprotein stability in the clinical tissue procurement process. Mol Cell Proteomics 2008; 7: 1998-2018.

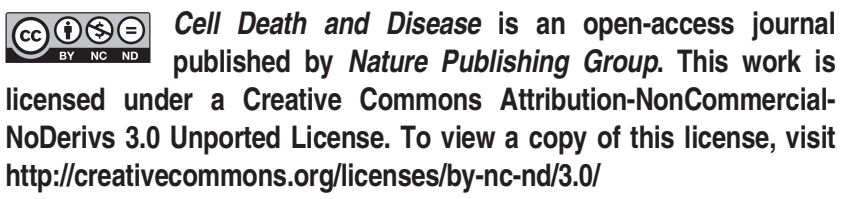

